\title{
Umbilical Cord Milking in Infants Born at $<37$ Weeks of Gestation: A Systematic Review and Meta-Analysis
}

\author{
Inmaculada Ortiz-Esquinas ${ }^{1}{ }^{(D}$, Juan Gómez-Salgado ${ }^{2,3}{ }^{\circledR}$, Julián Rodriguez-Almagro ${ }^{4, *}{ }^{\mathbb{C}}$, \\ Ángel Arias-Arias ${ }^{5}\left(\mathbb{D}\right.$, Ana Ballesta-Castillejos ${ }^{6}$ and Antonio Hernández-Martínez ${ }^{1,4}$ \\ 1 Department of Obstetrics \& Gynaecology, Alcázar de San Juan, 13600 Ciudad Real, Spain; \\ inmaores@hotmail.com (I.O.-E.); antomatron@gmail.com (A.H.-M.) \\ 2 Department of Sociology, Social Work and Public Health, University of Huelva, 21071 Huelva, Spain; \\ jgsalgad@gmail.com \\ 3 Safety and Health Postgraduate Programme, Espíritu Santo University, Guayaquil 091650, Ecuador \\ 4 Department of Nursing, Faculty of Nursing of Ciudad Real, University of Castilla-La Mancha, \\ 13071 Ciudad Real, Spain \\ 5 Research Support Unit, “Mancha-Centro” Hospital, Alcázar de San Juan, 13600 Ciudad Real, Spain; \\ angel_arias_arias81@hotmail.com \\ 6 Department of Obstetrics \& Gynaecology, Hospital Talavera de la Reina, 45600 Toledo, \\ Spain;ana.ballesta81@gmail.com \\ * Correspondence: julianj.rodriguez@uclm.es; Tel.: +346-7668-3843
}

Received: 20 February 2020; Accepted: 7 April 2020; Published: 9 April 2020

\begin{abstract}
Umbilical cord milking (UCM) could be an alternative in cases where delayed umbilical cord clamping cannot be performed, therefore our objective was to evaluate the effects of UCM in newborns $<37$ weeks' gestation. In this systematic review and meta-analysis, we searched MEDLINE, EMBASE, CINAHL, the Cochrane Database of Clinical Trials, the clinicaltrails.gov database for randomized UCM clinical trials with no language restrictions, which we then compared with other strategies. The sample included 2083 preterm infants. The results of our meta-analysis suggest that UCM in premature infants can reduce the risk of transfusion (relative risk $(\mathrm{RR})=0.78$ [95\% confidence interval $(\mathrm{CI}), 0.67-0.90]$ ) and increase hemoglobin(pooled weighted mean difference (PWMD) $=0.89 \mathrm{~g} / \mathrm{L}[95 \% \mathrm{CI} 0.55-1.22])$ and mean blood pressure (PWMD=1.92 $\mathrm{mmHg}$ [95\% CI 0.55-3.25]). Conversely, UCM seems to increase the risk of respiratory distress syndrome ( $R R=1.54$ [95\% CI 1.03-2.29]), compared to the control groups. In infants born at $<33$ weeks, $\mathrm{UCM}$ was associated with a reduced risk of transfusion $(\mathrm{RR}=0.81$ [95\%CI 0.66-0.99]), as well as higher quantities of hemoglobin (PWMD=0.91 g/L[95\%CI 0.50-1.32]). UCM reduces the risk of transfusion in preterm infants, and increases initial hemoglobin, hematocrit, and mean blood pressure levels with respect to controls.
\end{abstract}

Keywords: Umbilical cord milking; delayed umbilical cord clamping; immediate umbilical cord clamping; preterm infants; systematic review and meta-analysis

\section{Introduction}

Placental transfusion is the transfer of residual placental blood to the baby during birth and umbilical cord clamping. This transfer is part of the physiological transition from fetal to neonatal circulation [1].

The placenta can contain up to $40 \%$ of fetal blood volume [2]. In full-term infants, when delayed umbilical cord clamping (DCC) is performed, an additional 80-100 mL of blood is transferred and can contribute one third to one quarter of neonatal blood volume at birth [3]. In preterm infants, a randomized study of DCC versus immediate umbilical cord clamping (ICC) found an $18 \%$ increase in blood volume in the DCC group [4]. 
This is why the benefits and risks derived from the different ways of managing the umbilical cord in infants have been studied. With DCC, the observed effects include an increase in hemoglobin levels, reduced need for transfusion, an increase in iron deposits, and reduced rates of necrotizing enterocolitis [5-7].

Clinical practice guidelines (CPG) [8,9] and various scientific associations [10-12] recommend DCC in all births, whenever possible, due to its positive impact on neonatal health. Occasionally, it is not possible to perform DCC for varying reasons, such as immediate neonatal resuscitation or maternal hemodynamic instability. Umbilical cord milking (UCM) has been suggested as an alternative to DCC in these cases. This technique consists of milking the umbilical cord two to four times along a $10 \mathrm{~cm}$ or $20 \mathrm{~cm}$ length of cord, from the placenta toward the newborn $[13,14]$.

In 2015, a meta-analysis was published on the use of UCM which included seven randomized controlled trials (RCTs) [13]. The control groups were made up of infants who had received DCC or ICC. One study included in this meta-analysis was on full-term infants. The authors concluded that UCM in preterm infants resulted in higher levels of hemoglobin and hematocrit than in other types of clamping, and also found a reduced risk of oxygen being needed and a reduced risk of intraventricular hemorrhage if UCM was performed. Furthermore, in 2018, another meta-analysis was published including only two RCTs of preterm infants comparing the practice of UCM with DCC. The authors concluded that UCM may reduce intraventricular hemorrhage compared to DCC [15].

Despite the demonstrated benefits of UCM for preterm infants, it is still not standard practice in delivery care and requires a new review due to the large number of RCTs published in recent years [16-26]. It would be especially interesting to determine the benefits and risks by gestational age and by type of clamping (DCC or ICC) in the most significant variables.

Therefore, the main objective of this systematic review and meta-analysis was to evaluate the effects of UCM in infants born at less than 37 weeks' gestation. The secondary objective was to evaluate the effects of UCM stratified by gestational age ( $<33 / \geq 33$ weeks) and type of clamping (ICC/DCC).

\section{Materials and Methods}

This systematic review with meta-analysis was done in accordance with the preferred reporting items for systematic review and meta-analyses (PRISMA) declaration [27].

\subsection{Data Sources and Searches}

The search strategy was: (stripping OR milking OR squeezing) AND (umbilicus OR umbilical cord OR cord). A systematic search was performed of main database: Cochrane Library Plus, EMBASE, Scopus, PubMed, and ClinicalTrials.gov. The specific search strategy adapted to each database is provided in detail in Appendix A (Table A1).

The inclusion criteria were: (I) the type of study: RCT; (II) the population; including infants born at $<37$ weeks gestational age (GA).We made an initial decision to study three populations $(<37,<33$, and $\geq 33$ weeks GA) separately because the effects and the results of interest would be different for these two groups; and (III) the type of procedure, where we included studies that compared UCM with a control procedure (ICC or DCC). The exclusion criteria were RCTs that included both preterm and full-term infants without the possibility of obtaining separate information for each group.

RCTs were selected with no time or language restrictions. Two reviewers (IOE and JRA) independently evaluated the articles obtained from a literature search done using titles and summaries, in an initial stage. They then evaluated the full texts that had been selected. Any dispute was resolved by reaching a consensus. If this was not possible, a third reviewer (AHM) evaluated the articles.

The main outcome of our study was neonatal mortality before discharge from hospital and the secondary results were adaptation at birth variables (cord arterial $\mathrm{pH}$, Apgar score at 1 and $5 \mathrm{~min}$ ) and hematological variables (first hematocrit and hemoglobin levels measured within the first $24 \mathrm{~h}$ after birth, the need for red blood cell transfusion before being discharged, peak serum bilirubin, and hyperbilirubinemia requiring phototherapy). We also included mean blood pressure within the first 
6h after birth and short-term morbidities such as respiratory distress syndrome, hypotension in the first $24 \mathrm{~h}$ after birth requiring volume or inotropic support, intraventricular hemorrhage (any grade), need for oxygen at 28 days, necrotizing enterocolitis, sepsis, retinopathy of prematurity, patent ductus arteriosus, and duration of hospital stay.

\subsection{Data Extraction and Quality Assessment}

The three reviewers (IOE, AAA, and AHM) compiled the data and evaluated the quality independently. For the continuous outcomes, the averages and standard deviations (SD) were compiled whenever possible. When the averages and the SD were not available and originally appeared as the median and range or interquartile range, we attempted to contact the authors and ask for the results. When this was not possible, the results were converted to the mean and SD, using the methodology recommended in the Cochrane Handbook [28]. For the categorical outcomes, the counts of the study events were compiled.

The risk of bias in each study included was assessed using the criteria described in the Cochrane Handbook for Systematic Reviews of Interventions [29]. Seven domains were evaluated related with the risk of bias in each included study because there is evidence that these problems are associated with biased estimates of the treatment effect: (1) random sequence generation, (2) allocation concealment, (3) blinding of participants and personnel, (4) blinding of outcome assessment, (5) incomplete outcome data, (6) selective reporting, and (7) other bias. The opinions of the review authors were classified as "low risk", "high risk", or "uncertain risk" of bias.

\subsection{Data Synthesis}

For the categorical outcomes, relative risk (RR) was used together with confidence intervals of 95\% (95\% CI). Mantel-Haenszel fixed-effects models and Der Simonian-Laird random-effects models were used depending on the absence or presence of heterogeneity, respectively. The heterogeneity of the studies was estimated using $\mathrm{I}^{2}$ tests and Cochran's Q. $\mathrm{I}^{2}$ values of $<25 \%, 25 \%-50 \%$, and $>50 \%$ normally correspond to small, moderate, and large amounts of heterogeneity, respectively [30,31].

For the quantitative outcomes, the pooled weighted mean difference (PWMD) was used with a $95 \%$ confidence interval (CI). The publication bias was also evaluated using Egger's asymmetry test and Funnel plots (Figure A1) [32]. The statistical significance level was defined as 0.05 .

All calculations were done using the statistics software StatsDirect, version 2.7.9 (StatsDirect Ltd., Cheshire, England).

\subsection{Role of the Funding Source}

The funders of the study had no role in study design, data collection, data analysis, data interpretation, writing of the report, or the decision to submit the paper for publication. All authors had full access to all data in the study and had final responsibility for the decision to submit for publication.

\section{Results}

\subsection{Study Selection}

A total of 1579 studies were identified in the literature search. After eliminating duplicate articles, the 477 remaining documents were screened by title and summary. After applying the inclusion/exclusion criteria, 17 articles were selected for qualitative and quantitative analysis (meta-analysis; Figure 1) 


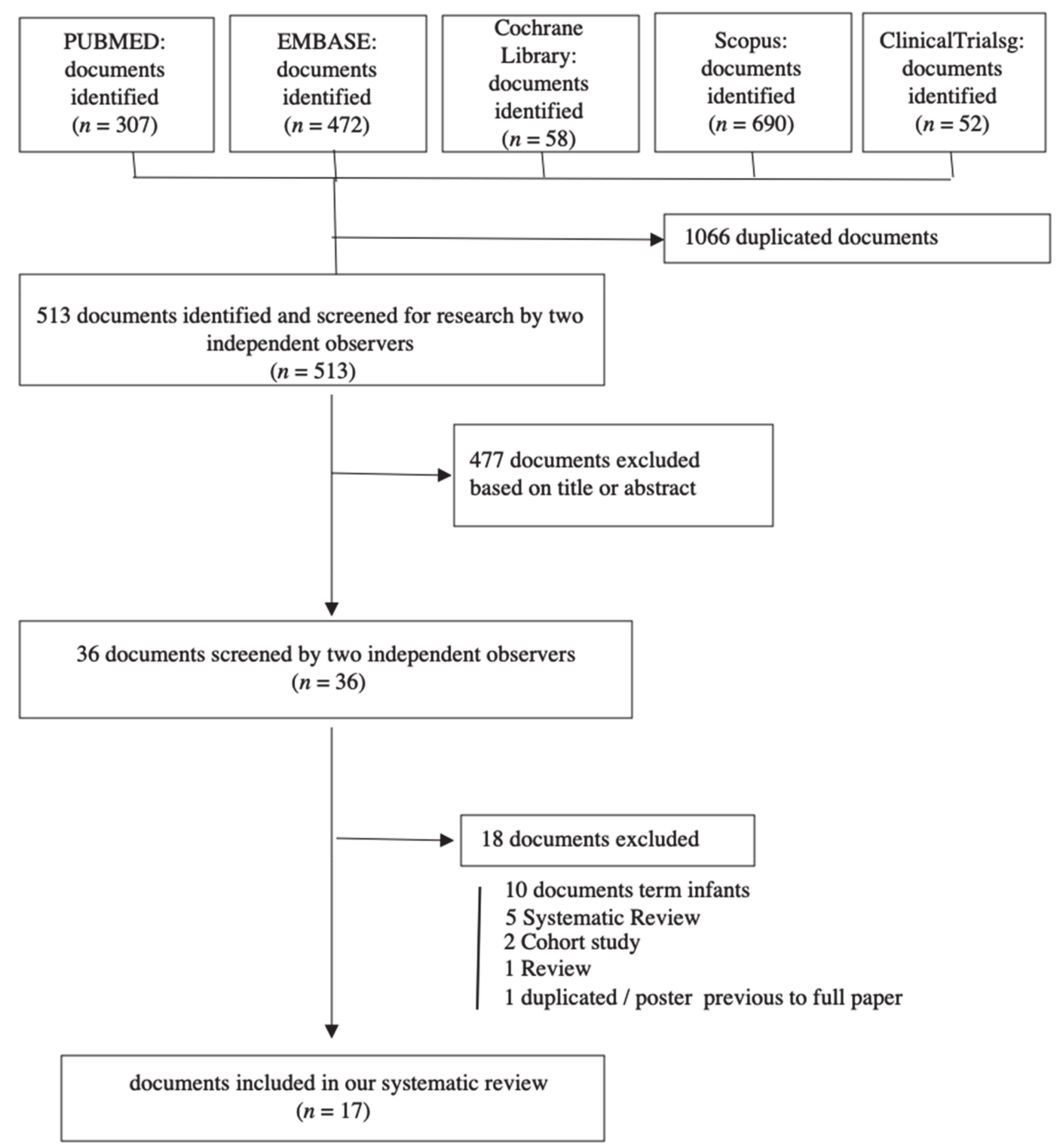

Figure 1. Preferred reporting items for systematic review and meta-analyses (PRISMA) flow diagram of the literature reviewing process.

\subsection{Study Characteristics}

The sample included 2083 preterm infants with GA between 23 and $<37$ weeks. The selected studies were from Japan [32], the United Kingdom [33], the United States [17,22,25,26,34-36], Turkey [19,37], India [18,20], South Korea [21], Canada [24,26], Ireland [26], and Germany [26].

The sample size of the studies ranged from 26 to 215 infants. UCM was compared with DCC in five RCTs $[17,22,25,26,36]$, with ICC in twelve RCTs [16,18-21,23,24,32-35,37].

The description of the UCM technique varied by study, including the number of times the cord was milked toward the baby (between two and four times) and the milking speed (between $5 \mathrm{~cm}$ within $1 \mathrm{~s}$ and $20 \mathrm{~cm}$ within $2 \mathrm{~s}$ ).

The number of infants in each study, the description of the UCM method, how the cord was managed in the control group, and the exclusion criteria are shown in Table 1. 
Table 1. Characteristics of the included studies.

\begin{tabular}{|c|c|c|c|c|c|c|c|c|}
\hline Author & Year & $N$ & Country & $\begin{array}{l}\text { Gestational } \\
\text { Age }\end{array}$ & $\begin{array}{c}\text { UCM } \\
\text { No. of Times }\end{array}$ & $\begin{array}{l}\text { UCM } \\
\text { Speed }\end{array}$ & $\begin{array}{l}\text { Control } \\
\text { Condition }\end{array}$ & Exclusion Criteria \\
\hline Hosono et al. & 2008 & 40 & Tokyo (Japan) & $24-28 w k$ & $2-3$ & $\begin{array}{c}20 \mathrm{~cm} \\
\text { within 2s }\end{array}$ & ICC & $\begin{array}{l}\text { Multiple births, major congenital anomalies, or } \\
\text { chromosomal anomalies and hydrops fetalis. }\end{array}$ \\
\hline Rabe et al. & 2011 & 58 & $\begin{array}{l}\text { Brighton } \\
\text { (United } \\
\text { Kingdom) }\end{array}$ & $24^{0 / 7}-32^{6 / 7} \mathrm{wk}$ & 4 & $\begin{array}{c}20 \mathrm{~cm} \\
\text { within } 2 \mathrm{~s}\end{array}$ & ICC & $\begin{array}{l}\text { Multiple births, inadequate time to obtain consent } \\
\text { before delivery, known congenital abnormalities of } \\
\text { the fetus, rhesus sensitization, or fetal hydrops. }\end{array}$ \\
\hline March et al. & 2013 & 75 & $\begin{array}{l}\text { Virginia } \\
\text { (USA) }\end{array}$ & $24-28 w k$ & 3 & - & ICC & $\begin{array}{l}\text { Antenatally diagnosed major fetal congenital } \\
\text { anomaly, known Factor Rh sensitization, hydrops } \\
\text { fetalis, known recent maternal exposure to } \\
\text { parvovirus, elevated peak systolic velocity of the } \\
\text { fetal middle cerebral artery, or clinical suspicion of } \\
\text { placental abruption at delivery due to excessive } \\
\text { maternal bleeding or uterine hypertonicity. }\end{array}$ \\
\hline Katheria et al. & 2014 & 60 & $\begin{array}{l}\text { San Diego } \\
\text { (USA) }\end{array}$ & $23^{0 / 7}-31^{6 / 7} \mathrm{wk}$ & 2 & $\begin{array}{l}20 \mathrm{~cm} \\
\text { within } 2 \mathrm{~s}\end{array}$ & ICC & $\begin{array}{l}\text { Monochorionic multiples, incarcerated mothers, } \\
\text { placenta previa, concern for abruptions, or refusal } \\
\text { to perform the intervention by the obstetrician. }\end{array}$ \\
\hline Alan et al. & 2014 & 44 & Ankara (Turkey) & $<32$ wk & 3 & $\begin{array}{l}5 \mathrm{~cm} \\
\text { within } 1 \mathrm{~s}\end{array}$ & ICC & $\begin{array}{l}\text { Suspected twin to twin transfusion syndrome or } \\
\text { discordant twins, major congenital anomalies or } \\
\text { chromosomal anomalies, vaginal bleeding due to } \\
\text { placenta previa or abruption or placental tear, } \\
\text { hemolytic disease of the fetus and newborn such as } \\
\text { rhesus sensitization, intrauterine growth restriction, } \\
\text { maternal gestational diabetes treated with insulin, } \\
\text { hydrops fetalis; and refused parental consent. }\end{array}$ \\
\hline Josephen et al. & 2014 & 26 & - & $24-26^{6 / 7} \mathrm{wk}$ & 3 & - & ICC & $\begin{array}{l}\text { Multiple gestation, congenital abnormalities, } \\
\text { hydrops fetalis, and known fetal anemia. }\end{array}$ \\
\hline Krueger et al. & 2015 & 67 & $\begin{array}{l}\text { South Alabama } \\
\text { (USA) }\end{array}$ & $22-31^{6 / 7} \mathrm{wk}$ & 4 & - & DCC & $\begin{array}{l}\text { The fetus had known anomalies or there was a } \\
\text { suspected placental abruption. }\end{array}$ \\
\hline
\end{tabular}


Table 1. Cont.

\begin{tabular}{|c|c|c|c|c|c|c|c|c|}
\hline Author & Year & $N$ & Country & $\begin{array}{c}\text { Gestational } \\
\text { Age }\end{array}$ & $\begin{array}{c}\text { UCM } \\
\text { No. of Times }\end{array}$ & $\begin{array}{l}\text { UCM } \\
\text { Speed }\end{array}$ & $\begin{array}{l}\text { Control } \\
\text { Condition }\end{array}$ & Exclusion Criteria \\
\hline Kumar et al. & 2015 & 200 & Northern India & $32^{0 / 7}-36^{6 / 7} w \mathrm{k}$ & 3 & $\begin{array}{c}10 \mathrm{~cm} \\
\text { within 1s }\end{array}$ & ICC & $\begin{array}{l}\text { Umbilical cord length less than } 25 \mathrm{~cm} \text {, or were } \\
\text { non-vigorous at birth, multiple births (twins, } \\
\text { triplets), those born to Rh negative or retrovirus } \\
\text { positive mothers, hydrops fetalis and those with } \\
\text { major congenital anomalies, cord prolapse or cord } \\
\text { anomalies like true knots were also excluded. } \\
\text { Babies born to mothers with complications such as } \\
\text { placental abruption, placental implantation } \\
\text { disorders (placenta previa or accreta), or } \\
\text { chorioamnionitis were excluded only if they were } \\
\text { born limp. }\end{array}$ \\
\hline Kilicdag et al. & 2015 & 54 & $\begin{array}{l}\text { Istanbul } \\
\text { (Turkey) }\end{array}$ & $\leq 32 \mathrm{wk}$ & 4 & $\begin{array}{c}20 \mathrm{~cm} \\
\text { within 2s }\end{array}$ & ICC & $\begin{array}{l}\text { Congenital anomalies, placenta abruption, } \\
\text { intrauterine growth restriction, twin-twin } \\
\text { transfusion syndrome, discordant twin growth, } \\
\text { vaginal delivery, and Rh hemolytic disease. }\end{array}$ \\
\hline Katheria et al. & 2015 & 154 & $\begin{array}{l}\text { San Diego } \\
\text { (USA) }\end{array}$ & $23^{0 / 7}-31^{6 / 7} w \mathrm{k}$ & 4 & $\begin{array}{c}20 \mathrm{~cm} \\
\text { within 2s }\end{array}$ & DCC & $\begin{array}{l}\text { Monochorionic multiples, incarcerated mothers, } \\
\text { placenta previa, concern for abruptions, Rh } \\
\text { sensitization, hydrops, congenital anomalies, or the } \\
\text { obstetrician declining to perform the intervention. }\end{array}$ \\
\hline Daset al & 2017 & 215 & Northern India & $30-33 w k$ & 2 & - & ICC & $\begin{array}{c}\text { Pregnant women with multiple pregnancies, } \\
\text { suspected or proven major congenital malformation } \\
\text { in the fetus, and antenatally diagnosed hydrops } \\
\text { fetalis. }\end{array}$ \\
\hline Song et al. & 2017 & 66 & $\begin{array}{l}\text { Chungnam } \\
\text { (South Korea) }\end{array}$ & $24^{0 / 7}-32^{6 / 7} \mathrm{wk}$ & 4 & $\begin{array}{c}20 \mathrm{~cm} \\
\text { within 2s }\end{array}$ & ICC & $\begin{array}{l}\text { Multiple gestations, rhesus sensitization, fetal } \\
\text { hydrops, or major fetal anomalies, and women } \\
\text { without antenatal written consent. }\end{array}$ \\
\hline
\end{tabular}


Table 1. Cont.

\begin{tabular}{|c|c|c|c|c|c|c|c|c|}
\hline Author & Year & $N$ & Country & $\begin{array}{c}\text { Gestational } \\
\text { Age }\end{array}$ & $\begin{array}{c}\text { UCM } \\
\text { No. of Times } \\
\end{array}$ & $\begin{array}{l}\text { UCM } \\
\text { Speed }\end{array}$ & $\begin{array}{c}\text { Control } \\
\text { Condition } \\
\end{array}$ & Exclusion Criteria \\
\hline Katheria et al. & 2017 & 135 & $\begin{array}{l}\text { San Diego } \\
\text { (USA) }\end{array}$ & $23^{0 / 7}-31^{6 / 7} w \mathrm{k}$ & 3 & - & DCC & $\begin{array}{l}\text { Monochorionic multiples, incarcerated mothers, } \\
\text { placenta previa, concern for placental abruption, Rh } \\
\text { sensitization, hydrops, and congenital anomalies. }\end{array}$ \\
\hline Lago et al. & 2018 & 138 & - & $24^{0}-36^{6} \mathrm{wk}$ & 4 & - & ICC & $\begin{array}{l}\text { Umbilical cord abnormalities (true and false knots, } \\
\text { short cord, nuchal cords), major congenital } \\
\text { anomalies or chromosomal anomalies, hydrops } \\
\text { fetalis twin-twin transfusion syndrome, clinical } \\
\text { suspicion or diagnosis of placental abruption, and } \\
\text { infants whose parents refused to consent. }\end{array}$ \\
\hline El-Naggar et al. & 2018 & 73 & $\begin{array}{c}\text { Halifax } \\
\text { (Canada) }\end{array}$ & $24-31 \mathrm{wk}$ & 3 & $\begin{array}{c}10 \mathrm{~cm} \\
\text { within 1s }\end{array}$ & ICC & $\begin{array}{c}\text { Monochorionic twins, major congenital anomalies, } \\
\text { placental abruption, fetal anemia, and intention to } \\
\text { withhold resuscitation. }\end{array}$ \\
\hline Shirk et al. & 2019 & 204 & $\begin{array}{l}\text { Cincinnati } \\
\text { (USA) }\end{array}$ & $23^{0}-34^{6} \mathrm{wk}$ & 4 & - & DCC & $\begin{array}{l}\text { Congenital anomalies that had been identified on } \\
\text { prenatal sonography (not including trisomy } \\
\text { markers), those with precipitous delivery that } \\
\text { prevented completion of the protocol, placental } \\
\text { abruption at the time of/or as the indication for } \\
\text { delivery, uterine rupture, infants known to be at } \\
\text { risk of anemia (i.e., parvovirus B19 infection and } \\
\text { allo/isoimmunization), or patient delivered at } \\
\text { outside institution after random assignment. }\end{array}$ \\
\hline Katheria et al. & 2019 & 474 & $\begin{array}{l}9 \text { participating } \\
\text { sites (6 in the } \\
\text { United States } \\
\text { and } 1 \text { site in } \\
\text { Ireland, } \\
\text { Germany, and } \\
\text { Canada) }\end{array}$ & $<32 w k$ & 3 & $\begin{array}{c}20 \mathrm{~cm} \\
\text { within 2s }\end{array}$ & DCC & $\begin{array}{l}\text { Major congenital anomalies, severe placental } \\
\text { abruption, transplacental incision, umbilical cord } \\
\text { prolapse, hydrops, bleeding accreta, monochorionic } \\
\text { multiple births, fetal or maternal risk for severe } \\
\text { compromise at delivery, and family unlikely to } \\
\text { return for } 24 \text { month neurodevelopmental testing. }\end{array}$ \\
\hline
\end{tabular}

Abbreviations: wk, weeks; ICC, immediate cord clamping; DCC, delayed cord clamping; UCM, umbilical cord milking. 


\subsection{Study and Data Quality}

The risk of bias for the seven domains of each study is shown in Figure A2. Ten of the 17studies were assessed as being low risk for random sequence generation; in four studies, the risk was not clear, and three were assessed as being high risk because the details of the methods used for randomization were not described. All of the studies stated that the health professionals involved could not be blinded due to the nature of the intervention. Table A2.

\subsection{Meta-Analysis}

\subsubsection{Mortality}

Eleven studies [17,21,23-26,32-36] evaluated the risk of mortality in 1409 infants at <37 weeks GA and found no significant reduction in the risk of mortality regarding the UCM group versus the control group ( $R R=0.71$ [95\% CI 0.47-1.08]). Similarly, in nine studies [17,21,24,26,32-36] that evaluated the mortality of 1067 infants at $<33$ weeks GA, no reduction in the risk of mortality was found in the intervention group versus the control group $(R R=0.66$ [95\% CI 0.43-1.03]). No significant differences were found in the sub-analysis by type of control (Tables 2 and A3).

\subsubsection{Phototherapy}

No significant differences were observed with regard to phototherapy between the intervention and control groups for five studies at $<37$ weeks GA $[20,23-25,34]$ and in three studies $[20,24,34]$ at $<33$ weeks GA (Tables 2 and A3).

\subsubsection{Transfusion}

Upon combining eight studies $[23,25,32-37]$ on infants at $<37$ weeks GA and six studies at $<33$ weeks GA [32-37], we found a reduction in the risk of transfusion in the intervention groups versus the control group, with an RR of 0.78 (95\% CI 0.67-0.90)and an RR of 0.81 (95\% CI 0.66-0.99), respectively. The NNT (Number Needed to Treat) to avoid it was 11 (CI 95\% 7-25) for those under 37 weeks and eight (CI 95\% 5-19) for those under 33 weeks. Figure 2a,b.

Furthermore, when we looked at six studies that had ICC as a control group [23,32-35,37], we observed that this practice was related with a decreased risk of transfusion in the intervention groups $(\mathrm{RR}=0.80$ [95\% CI 0.68-0.94];Figure 2c,Table 2, and Table A3).

\subsubsection{Hemoglobin}

Upon grouping fourteen studies on infants born at $<37$ weeks GA [16,18-26,32,34,36,37], we observed that in the UCM group, hemoglobin levels within the first $24 \mathrm{~h}$ after birth were statistically higher than in the control group (PWMD $=0.89 \mathrm{~g} / \mathrm{L}$ [95\% CI 0.55-1.22]). We also observed that in eleven studies of infants born at $<33$ weeks GA [16,19-22,24,26,32,34,36,37], there was an increase in hemoglobin levels in the intervention group (PWMD $=0.91 \mathrm{~g} / \mathrm{L}$ [95\% CI 0.50-1.32]). Likewise, we also observed that in 542 infants at $>33$ weeks there was an increase in hemoglobin levels in the intervention group (PWMD = $0.85 \mathrm{~g} / \mathrm{L}$ [95\% CI 0.17-1.53]; Figure 2d,e).

Furthermore, when we looked at 10studies that had ICC as a control group [16,18-21,23,24,32,34,37], we observed that this practice was related with increased hemoglobin compared with the intervention group (PWMD = 1.14 g/L [95\% CI 0.83-1.44]).

When we studied the UCM group versus the DCC group [16,22,25,26,36], we observed an increase in hemoglobin levels in the intervention group (PWMD = 0.38 g/L [95\% CI 0.06-0.70]; Tables 2 and A4).

\subsubsection{Hematocrit}

To assess the hematocrit, we examined nine studies [17,19,20,23,25,26,33-35] and found hematocrit levels were not higher in the UCM intervention group than in the control group 
(PWMD $=1.43$ million $/ \mathrm{mm}^{3}$ [95\% CI -0.03-2.89]). However, when we studied 342infants born at $>33$ weeks, we observed an increase in hematocrit levels in the intervention group (PWMD $=2.90$ million/ $/ \mathrm{mm}^{3}[95 \%$ CI 1.28-4.52]; Figure 2h. Table 2, and Table A4).

\subsubsection{Peak Serum Bilirubin}

No significant differences were observed in peak serum bilirubin regarding the intervention and control groups in nine studies $<37$ weeks GA [17,23-25,32-36] (Tables 2 and A4).

\subsubsection{Mean blood pressure.}

In six studies $[18,21,24,32,33,35]$, it was observed that the mean blood pressure of the UCM group was greater than that in the control group (PWMD $=2.47 \mathrm{mmHg}$ [95\% CI 0.39-4.55]). We did not find significant differences in the analysis by type of control and GA (Figure 2g, Table 2, and Table A4).

\subsubsection{Respiratory Distress Syndrome}

Four studies were used to assess respiratory distress syndrome [18,23,32,34]. We observed that the risk of respiratory distress syndrome was higher in the UCM group than in the control group $(\mathrm{RR}=1.54$ [95\% CI 1.03-2.29]). However, when we studied 338 infants born at $>33$ weeks, we observed that the risk of respiratory distress syndrome was higher in the intervention group. No significant differences were found in the sub-analysis of the type of control (Figure 2f, Table 2, and Table A3).

\subsection{Other Variables}

No inter-group differences were found for length of hospital stay, cord arterial $\mathrm{pH}$, Apgar scores $1 \mathrm{~min}$, Apgar scores $5 \mathrm{~min}$, oxygen at birth, oxygen at 28 days, retinopathy of prematurity, using hypotensive expanders, using hypotensive drugs, necrotizing enterocolitis, patent ductus arteriosus, sepsis, and intraventricular hemorrhage (Tables 2, A3 and A4).

\subsection{Publication Bias}

Publication bias was observed for the hematocrit study (Egger's test for asymmetry; $p=0.037$ ), mean blood pressure (Egger's test for asymmetry; $p=0.007$ ), and for length of hospital stay (Egger's test for asymmetry; $p=0.039$; Table 2 and Figure A1). 
Table 2. Comparison of umbilical cord milking vs. control intervention.

\begin{tabular}{|c|c|c|c|c|c|c|c|c|}
\hline Outcome & $\begin{array}{c}\text { Gestational } \\
\text { Age }\end{array}$ & No of Studies & $\begin{array}{c}\text { No of } \\
\text { Participants }\end{array}$ & $\operatorname{RR}(95 \% \mathrm{CI}) \mathrm{b}$ & PWMD (95\% CI)b & I 2 Value, \% & Cochran's Q & Egger Bias \\
\hline \multirow{5}{*}{ Mortality } & $<37$ weeks & 11 & 1.409 & $0.71(0.47-1.08)$ & & $0 \%(0-52.7)$ & 0.482 & 0.165 \\
\hline & $<33$ weeks & 9 & 1.067 & $0.66(0.43-1.03)$ & & $0 \%(0-54.4)$ & 0.455 & 0.166 \\
\hline & $\geq 33$ weeks & $\mathrm{NC}$ & NC & $\mathrm{NC}$ & & NC & NC & $\mathrm{NC}$ \\
\hline & ICC control & 7 & 510 & $0.51(0.26-1.06)$ & & $0 \%(0-61)$ & 0.687 & 0.073 \\
\hline & DCCcontrol & 4 & 899 & $0.87(0.52-1.47)$ & & $23.3 \%(0-74.8)$ & 0.271 & 0.177 \\
\hline \multirow{5}{*}{ Transfusion } & $<37$ weeks & 8 & 767 & $0.78(0.67-0.90)$ & & $42.1 \%(0-72.9)$ & 0.098 & 0.345 \\
\hline & $<33$ weeks & 6 & 425 & $0.80(0.69-0.92) *$ & & $53 \%(0-79.3)$ & 0.059 & 0.483 \\
\hline & $\geq 33$ weeks & 2 & 342 & $0.64(0.33-1.23)$ & & NC & 0.680 & $\mathrm{NC}$ \\
\hline & ICC control & 6 & 409 & $0.80(0.68-0.94)$ & & $53 \%(0-79.3)$ & 0.059 & 0.567 \\
\hline & DCC control & 2 & 358 & $-0.08(-0.16-0.00)$ & & NC & 0.621 & $\mathrm{NC}$ \\
\hline \multirow{5}{*}{ Hemoglobin } & $<37$ weeks & 14 & 1.830 & & $0.89(0.55$ to 1.22$) *$ & $53 \%(0-73)$ & 0.01 & 0.037 \\
\hline & $<33$ weeks & 11 & 1.288 & & $0.91(0.50$ to 1.32$)$ * & $56 \%(0-76)$ & 0.012 & 0.104 \\
\hline & $\geq 33$ weeks & 3 & 542 & & $0.85(0.17$ to 1.53$)$ * & $59.6 \%(0-86.6)$ & 0.084 & $\mathrm{NC}$ \\
\hline & ICC control & 10 & 863 & & $1.14(0.83$ to 1.44$)$ & $36.4 \%(0-68.5)$ & 0.117 & 0.716 \\
\hline & DCC control & 4 & 967 & & $0.38(0.06$ to 0.70$)$ & $0 \%(0-67.9)$ & 0.549 & 0.011 \\
\hline \multirow{5}{*}{ Phototherapy } & $<37$ weeks & 5 & 687 & $1.03(0.92-1.15)$ * & & $81.9 \%(46.5-90.5)$ & 0.001 & 0.208 \\
\hline & $<33$ weeks & 3 & 345 & $0.99(0.95-1.02)$ & & $17.1 \%(0-77.2)$ & 0.299 & $\mathrm{NC}$ \\
\hline & $\geq 33$ weeks & 2 & 342 & $1.15(1.00-1.31)$ & & NC & 0.033 & NC \\
\hline & ICC control & 4 & 483 & $1.06(0.89-1.26)$ * & & $90.2 \%(76-94.5)$ & $<0.001$ & 0.294 \\
\hline & DCC control & 1 & 204 & $1.00(0.89-1.12)$ & & NC & NC & $\mathrm{NC}$ \\
\hline \multirow{5}{*}{ Hematocrit } & $<37$ weeks & 9 & 804 & & $1.43(-0.03$ to 2.89$) *$ & $61.2 \%(0-79.5)$ & 0.008 & 0.526 \\
\hline & $<33$ weeks & 7 & 700 & & $0.57(-0.41$ to 1.55$)$ & $46.1 \%(0-75.6)$ & 0.084 & 0.616 \\
\hline & $>33$ weeks & 2 & 342 & & $2.90(1.28$ to 4.52$)$ & NC & 0.057 & NC \\
\hline & ICC control & 6 & 533 & & $1.93(-0.41$ to 4.28$)$ * & $67.5 \%(0-84.3)$ & 0.009 & 0.732 \\
\hline & DCC control & 3 & 745 & & $0.61(-0.48$ to 1.70$)$ & $22.3 \%(0-78.4)$ & 0.276 & NC \\
\hline \multirow{5}{*}{$\begin{array}{c}\text { Respiratory } \\
\text { distress } \\
\text { syndrome }\end{array}$} & $<37$ weeks & 4 & 453 & $1.54(1.03-2.29)$ & & $39.6 \%(0-82.3)$ & 0.191 & NC \\
\hline & $<33$ weeks & $\mathrm{NC}$ & NC & $\mathrm{NC}$ & & $\mathrm{NC}$ & $\mathrm{NC}$ & $\mathrm{NC}$ \\
\hline & $>33$ weeks & 2 & 338 & $2(1.07-3.73)$ & & NC & $>0.999$ & $\mathrm{NC}$ \\
\hline & ICC control & $\mathrm{NC}$ & NC & NC & & NC & $\mathrm{NC}$ & $\mathrm{NC}$ \\
\hline & DCC control & NC & NC & NC & & NC & NC & NC \\
\hline
\end{tabular}


Table 2. Cont.

\begin{tabular}{|c|c|c|c|c|c|c|c|c|}
\hline Outcome & $\begin{array}{c}\text { Gestational } \\
\text { Age }\end{array}$ & No of Studies & $\begin{array}{c}\text { No of } \\
\text { Participants }\end{array}$ & $\mathrm{RR}(95 \% \mathrm{CI}) \mathrm{b}$ & PWMD (95\% CI)b & I 2 Value, $\%$ & Cochran's Q & Egger Bias \\
\hline \multirow{5}{*}{$\begin{array}{l}\text { Intraventricular } \\
\text { hemorrhage }\end{array}$} & $<37$ weeks & 13 & 1.713 & $0.93(0.76-1.15)$ & & $11.1 \%(0-54.1)$ & 0.334 & 0.787 \\
\hline & $<33$ weeks & 11 & 1.233 & $0.97(0.77-1.20)$ & & $20.3 \%(0-60.5)$ & 0.25 & 0.814 \\
\hline & $>33$ weeks & 2 & 342 & $0.72(0.38-1.38)$ & & NC & 0.58 & $\mathrm{NC}$ \\
\hline & ICC control & 8 & 345 & $0.83(0.6-1.16)$ & & $15.8 \%(0-62.8)$ & 0.305 & 0.271 \\
\hline & DCC control & 5 & 518 & $1(0.77-1.31)$ & & $0 \%(0-64.1)$ & 0.413 & 0.447 \\
\hline $\begin{array}{c}\text { Peak serum } \\
\text { bilirubin }\end{array}$ & $<37$ weeks & 9 & 869 & & $0.11(-0.18$ to 0.40$)$ & $35 \%(0-69)$ & 0.138 & 0.313 \\
\hline $\begin{array}{l}\text { Mean blood } \\
\text { pressure }\end{array}$ & $<37$ weeks & 6 & 497 & & $1.92(0.55$ to 3.25$)$ & $52.9 \%(0-79.3)$ & 0.059 & 0.007 \\
\hline $\begin{array}{c}\text { Length of } \\
\text { hospital stay }\end{array}$ & $<37$ weeks & 5 & 308 & & $-1.92(-8.44$ to 4.60$)$ & $24.1 \%(0-72.1)$ & 0.260 & 0.039 \\
\hline Cord arterial $\mathrm{pH}$ & $<37$ weeks & 4 & 380 & & $-0.03(-0.05$ to 0.01$)$ & $0 \%(0-67.9)$ & 0.705 & 0.969 \\
\hline $\begin{array}{l}\text { Apgar scores } 1 \\
\text { min }\end{array}$ & $<37$ weeks & 8 & 756 & & $0.02(-0.06$ to 0.10$)$ & $0.0 \%(0-56.3)$ & 0.455 & 0.1 \\
\hline $\begin{array}{c}\text { Apgar scores } 5 \\
\text { min }\end{array}$ & $<37$ weeks & 9 & 766 & & $0.02(-0.31$ to 0.35$) *$ & $72.1 \%(33.9-84.2)$ & 0.001 & 0.177 \\
\hline Oxygen at birth & $<37$ weeks & 3 & 293 & $1.01(0.82-1.23)^{*}$ & & $67.2 \%(0-88.4)$ & 0.047 & $\mathrm{NC}$ \\
\hline $\begin{array}{c}\text { Oxygen at } 28 \\
\text { days }\end{array}$ & $<37$ weeks & 2 & 212 & $1.20(0.67-2.14)$ & & $\mathrm{NC}$ & 0.375 & $\mathrm{NC}$ \\
\hline $\begin{array}{l}\text { Retinopathy of } \\
\text { prematurity }\end{array}$ & $<37$ weeks & 9 & 1.204 & $0.80(0.63-1.03)$ & & $35.2 \%(0-69.1)$ & 0.136 & 0.688 \\
\hline $\begin{array}{c}\text { Hypotensive } \\
\text { expanders }\end{array}$ & $<37$ weeks & 2 & 133 & $1.00(0.53-1.88)$ & & $\mathrm{NC}$ & 0.475 & $\mathrm{NC}$ \\
\hline $\begin{array}{l}\text { Hypotensive } \\
\text { drugs }\end{array}$ & $<37$ weeks & 6 & 547 & $0.70(0.48-1.03)$ & & $7.3 \%(0-63.8)$ & 0.370 & 0.299 \\
\hline $\begin{array}{l}\text { Necrotizing } \\
\text { enterocolitis }\end{array}$ & $<37$ weeks & 10 & 1.477 & $0.71(0.45-1.12)$ & & $0 \%(0-52.7)$ & 0.920 & 0.315 \\
\hline $\begin{array}{l}\text { Patent ductus } \\
\text { arteriosus }\end{array}$ & $<37$ weeks & 4 & 725 & $1.04(0.78-1.40)$ & & $11.7 \%(0-71.5)$ & 0.334 & 0.595 \\
\hline Sepsis & $<37$ weeks & 9 & 1.237 & $0.96(0.77-1.19)$ & & $0 \%(0-54.4)$ & 0.615 & 0.205 \\
\hline
\end{tabular}

NC, Not calculated; CI, Confidence Interval; RR, relative Risk; PWMD, pooled weighted mean difference; PWMD, pooled weighted mean difference; ${ }^{*}$ Random effects (DerSimonian-Laird). Bold means statistically significant differences. 


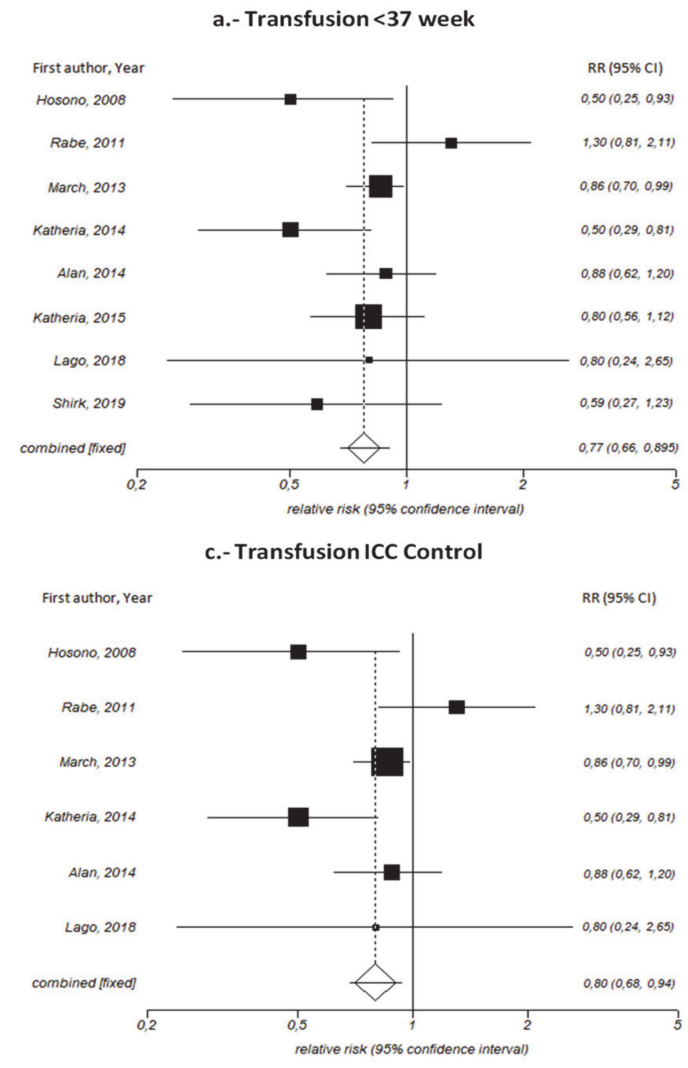

e.- Hemoglobin <33 week

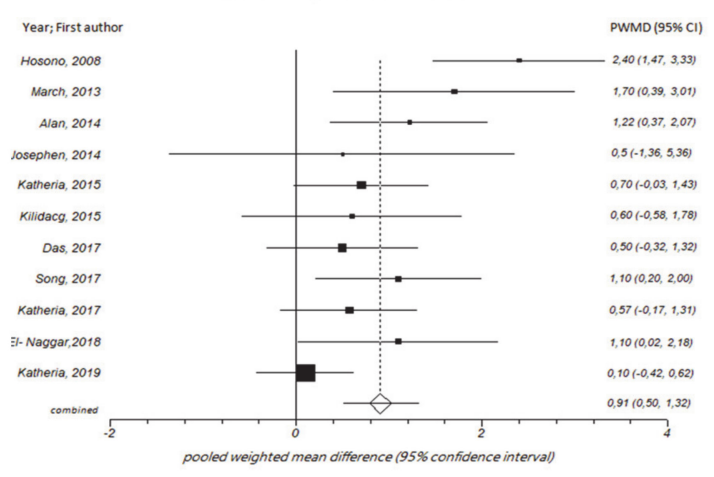

g.- Mean blood pressure

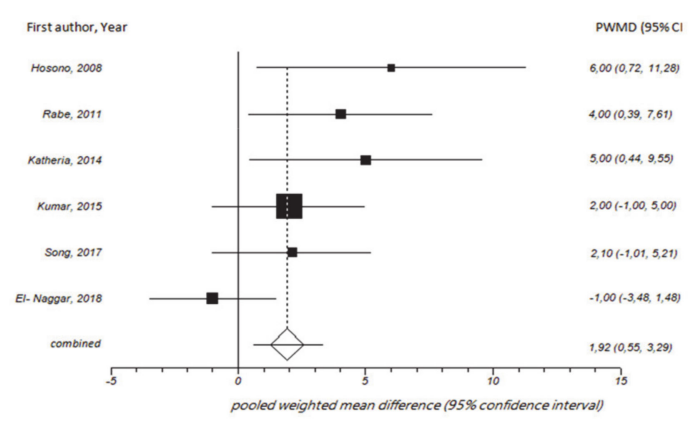

b.- Transfusion <33 week

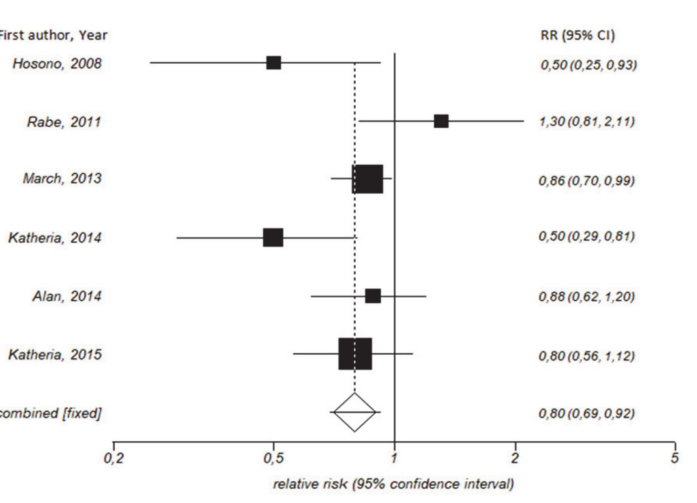

d.- Hemoglobin <37 week

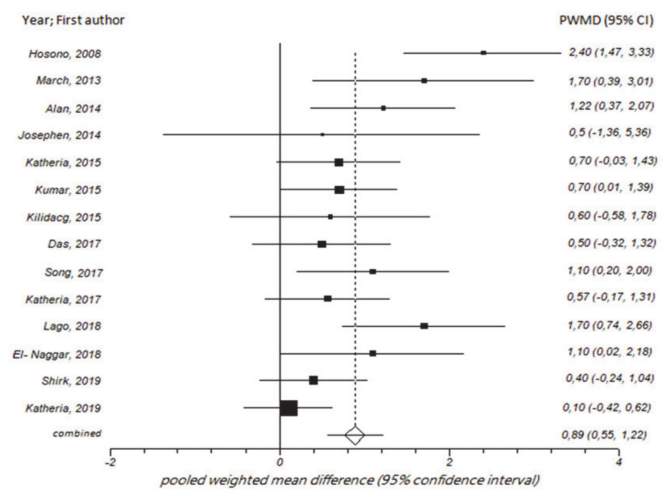

f.- Respiratory distress

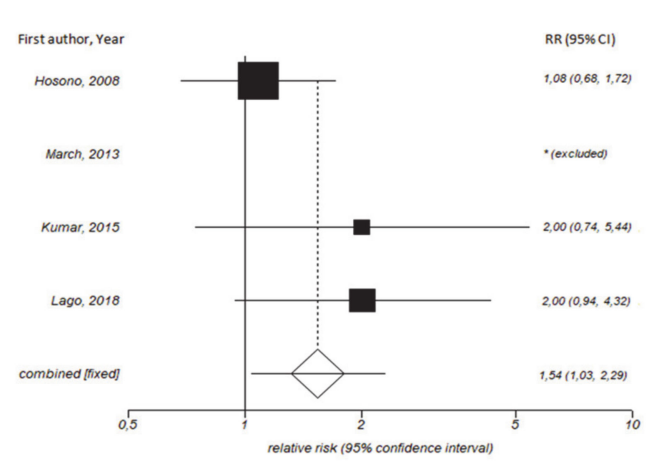

h.- Hematocrit ICC Control

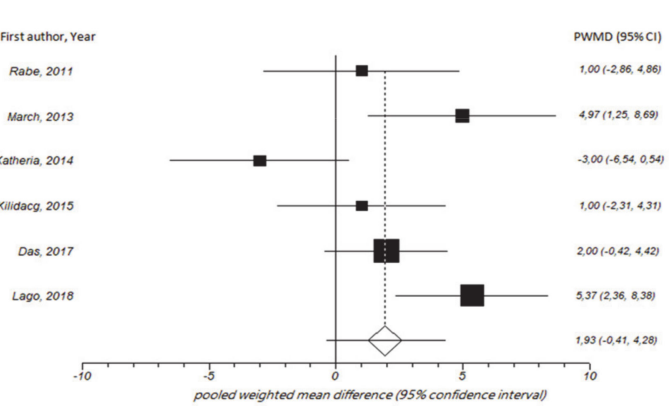

Figure 2. Forest plot. 


\section{Discussion}

\subsection{Main Findings}

The results of our meta-analysis suggest that UCM in preterm infants may reduce the risk of transfusion and increase hemoglobin and mean arterial pressure values. The only adverse effect of UCM appears to be that it increases the risk of respiratory distress syndrome compared to control groups.

With regard to meta-analysis by gestational age, in infants born with $<33$ weeks of GA, UCM was associated with a reduced risk of transfusion and with higher hemoglobin levels compared to the control group. In infants born with $>33$ weeks, higher hematocrit levels were observed in the intervention group versus the control group.

Moreover, upon conducting the meta-analysis according to the type of controls, the only statistical differences observed was the increase in hemoglobin levels in the UCM group versus ICC and DCC.

\subsection{Interpretation}

In our review we found an increase in hemoglobin levels, which reduces the risk of anemia, as well as the need for transfusion and the complications associated with this practice [38,39]. Specifically, the improvement in hematology is due to the placenta containing approximately $15-20 \mathrm{~mL}$ of blood per kilogram of body weight, regardless of birth weight [2], and when performing the UCM there is an increase in systemic blood volume and, therefore, in fetal hemoglobin. These improvements in hematological values were also observed in previous studies by Al-Wassia et al. and Dang et al. [13,40].

In our study, no significant differences were found regarding intraventricular hemorrhage between the intervention group and the controls, nor when performing the sub-analysis by GA or type of clamping. However, in 2019, one study [26] was discontinued due to concerns of increased severe IVH (Intraventricular Hemorrhage) in the overall cohort and a significant difference in the premature subgroup, $<28$ weeks. In our study, the cut-off point of gestational age was set at $<33$ weeks, and previous trials included in the meta-analysis were underpowered to find such effects. Therefore, the result of this variable must be taken with caution as new trials are required to confirm these data. Therefore, until this safety is verified with other studies, this practice should not be recommended in fetuses $<28$ weeks.

With regard to the adaptive capacity of the infant to life, no significant differences were observed in the Apgar scores at one or five minutes, cord arterial $\mathrm{pH}$, or need for oxygen at birth between the UCM group and the control groups. An increased risk of respiratory distress was observed in infants with UCM, although only four studies were included for this meta-analysis.

When we carried out sub-analysis by GA, we found a reduced need for transfusion, and in increase in hemoglobin levels in preterm infants born at $<33$ weeks GA. However, these improvements were not observed in the $>33$ weeks GA group, which is attributable to the fact that only 2-3 RCTs were included, and also to the lack of information on several of the variables included. In the sub-analysis by type of control, where we compared UCM to ICC or DCC, we can only confirm an improvement in hemoglobin levels in the UCM group compared to the other two types of controls. In this regard, new trials are needed to confirm the benefits of UCM in infants at $>33$ weeks GA and, especially, to compare it with DCC.

Studies are currently being conducted on animals, that have raised major concerns about the safety of UCM in lambs at $126 \pm 1$ days gestation (equivalent to approximately 26 weeks gestational age in humans), with spikes in blood pressure and cerebral blood flow during each milking, which are detrimental to the newborn. [41]. In this respect, more studies covering a wider range of gestational ages would be necessary to raise these concerns and thus be able to compare the different studies. 


\subsection{Strengths and Limitations}

The main strength of this systematic review is the inclusion of 11 new RCTs compared with the last review published. It also analyzes the effect of UCM in different sub-populations by gestational age and type of control, as well as assessing publication bias.

One of the limitations of our systematic review is that the inclusion and exclusion criteria were very variable, therefore there is a large amount of heterogeneity in the study populations. We also observed that the variables measured varied widely between each study. Another limitation is the lack of standardization of the practice of UCM in the different studies, although the method is described in detail in the majority of them. We observed a publication bias in the result "mean blood pressure", which could mean that the UCM group is overestimated, so the results should be interpreted with caution. On the other hand, we have not assessed the effects of UCM on severe intra-ventricular hemorrhage, and we do not have these data on long-term effects. The low number of studies that compare UCM with DCC means that is not possible to establish conclusive results.

\section{Conclusions}

The main conclusion of our systematic review is that UCM increases initial hemoglobin and mean blood pressure levels and reduces the risk of transfusion in preterm infants. There are no complications associated with this practice regarding the studied variables, except for an increased risk of respiratory distress syndrome. The UCM does not increase neonatal mortality compared to DCC and ICC procedures. In this sense, UCM could be considered as an alternative to DCC in situations where this cannot be carried out in fetuses $>28$ weeks, although the preferred technique should still be DCC.

Author Contributions: Conceptualization, I.O.-E and J.R.-A.; Methodology, A.H.-M. and A.A.-A.; Formal Analysis, J.G.-S., A.H.-M., and A.B.-C.; Writing-Original Draft Preparation, I.O.-E. and J.R.-A.; Writing-Review and Editing, A.A.-A. and A.H.-M.; Supervision, A.B.-C. and A.H.-M.; Project Administration, J.G.-S. All authors have read and agreed to the published version of the manuscript.

Funding: This research received no external funding

Conflicts of Interest: The authors declare no conflict of interest.

\section{Appendix A}

Table A1. Search strategies.

\begin{tabular}{|c|c|c|}
\hline Database & Search Strategies & Hits \\
\hline Pubmed & 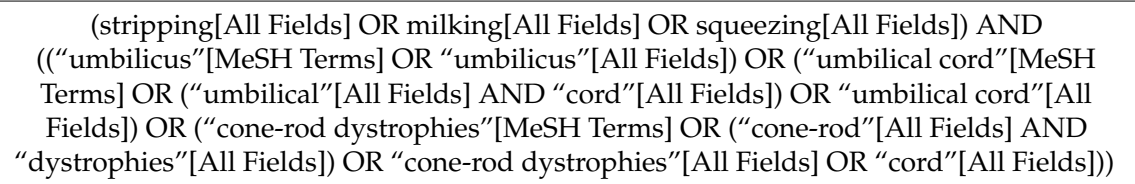 & 307 \\
\hline Embase & $\begin{array}{c}\text { ('stripping'/exp OR stripping OR ‘milking'/exp OR milking OR squeezing) AND } \\
\text { ('umbilicus'/exp OR umbilicus OR 'umbilical cord'/exp OR 'umbilical cord' OR } \\
\text { (('umbilical'/exp OR umbilical) AND cord) OR cord) }\end{array}$ & 472 \\
\hline Scopus & (stripping OR milking OR squeezing) AND (umbilicus OR umbilical AND cord OR cord) & 690 \\
\hline Clinical trials & (stripping OR milking OR squeezing) AND (umbilical cord OR cord) & 52 \\
\hline $\begin{array}{l}\text { Cochrane } \\
\text { Library plus }\end{array}$ & (stripping OR milking OR squeezing) AND (umbilicus OR umbilical AND cord OR cord) & 58 \\
\hline
\end{tabular}




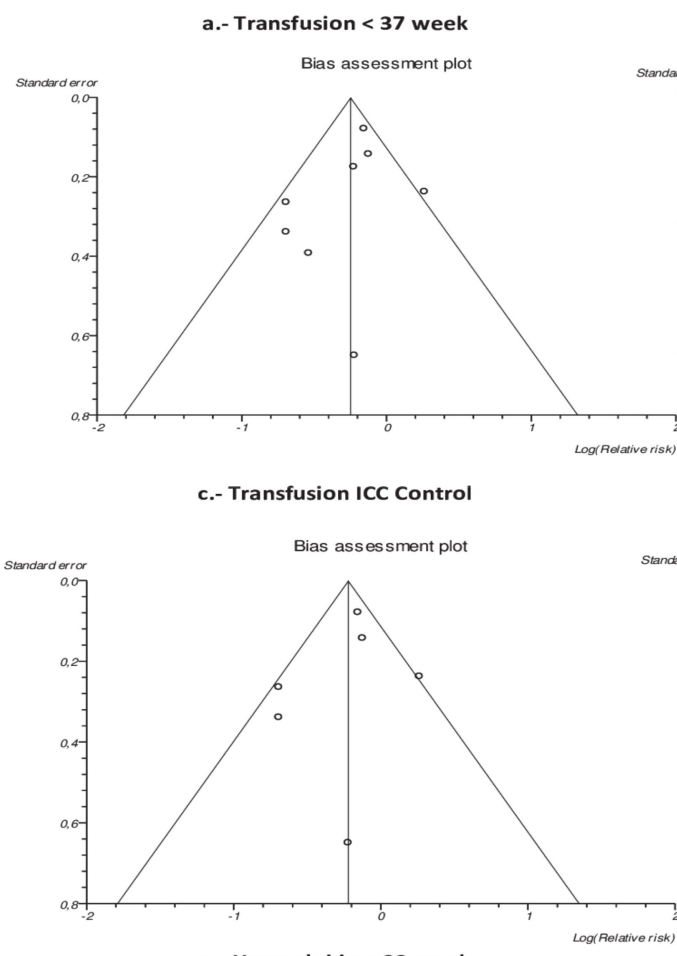

e.- Hemoglobin < 33 week

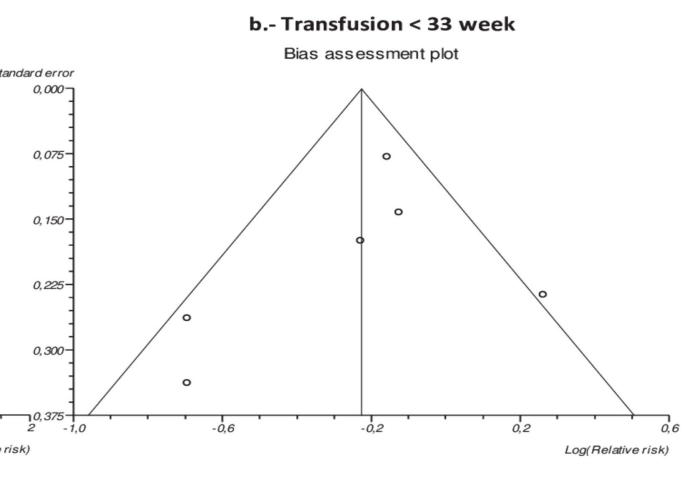

Bias assessment plot

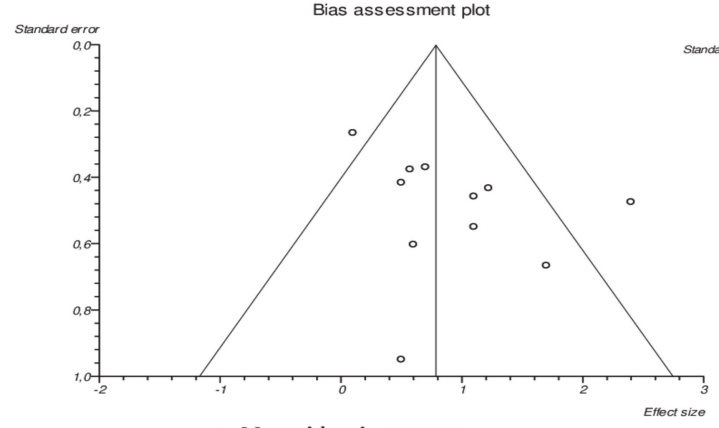

g.- Mean blood pressure

d.- Hemoglobin < 37 week

Bias assessment plot

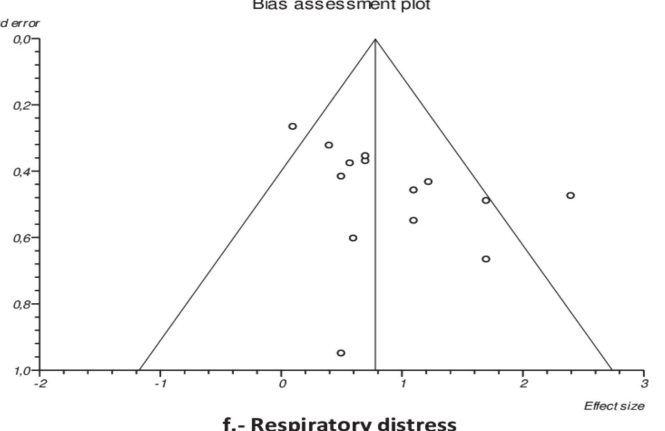

f.- Respiratory distress

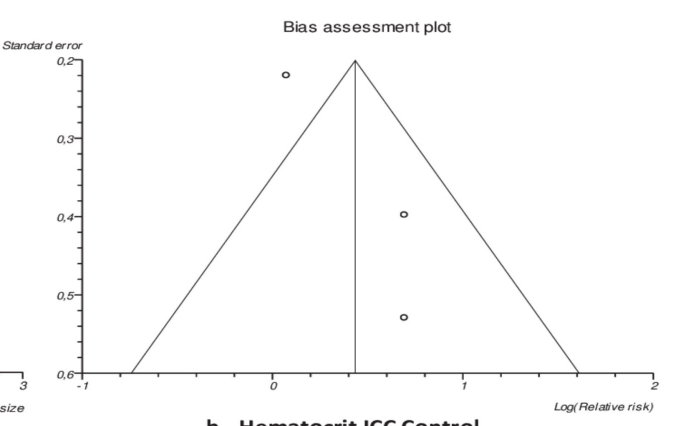

h.- Hematocrit ICC Control

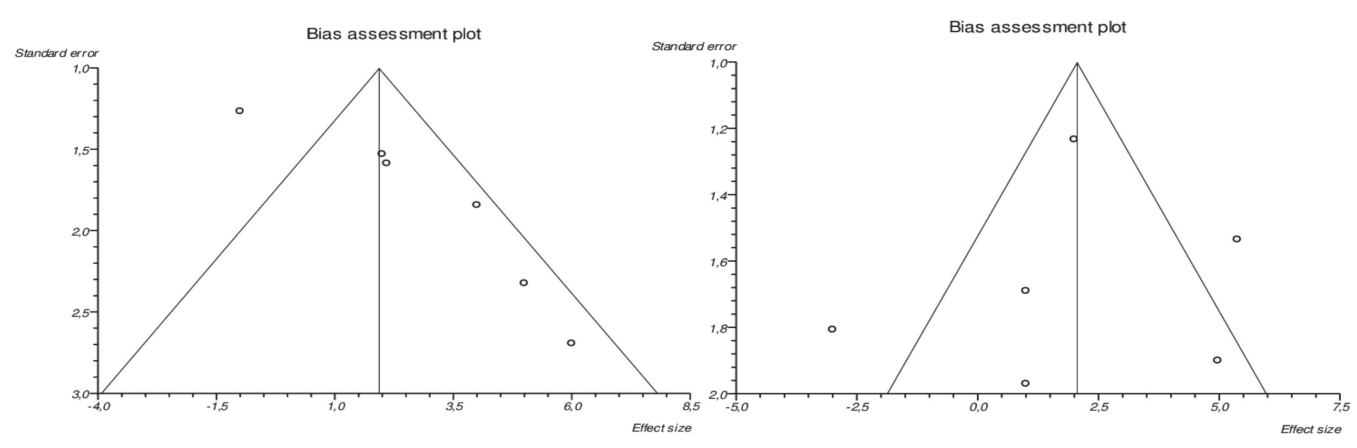

Figure A1. Funnel Plot. 

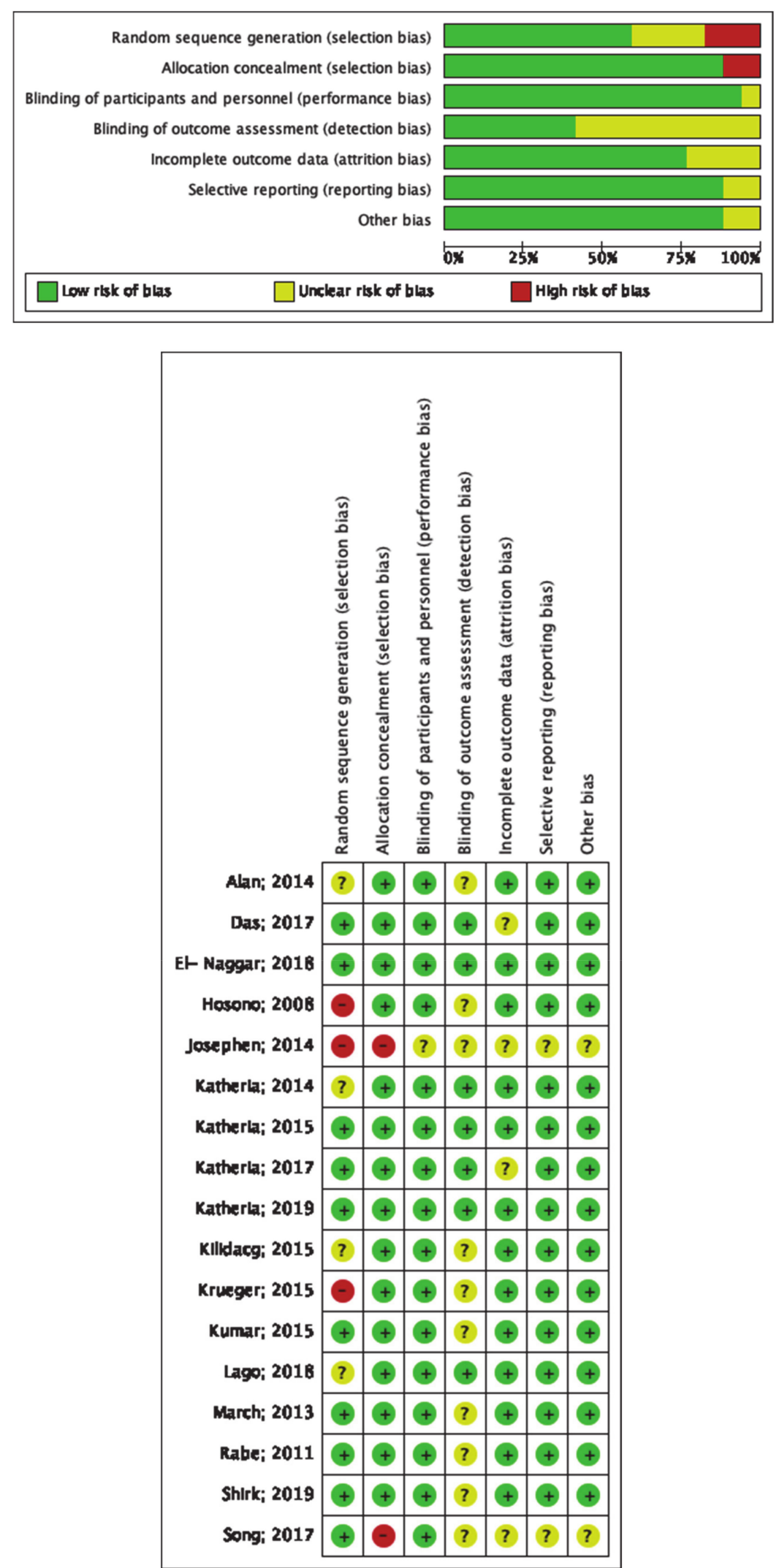

Figure A2. Assessment of the Risk of Bias. 
Table A2. Assessment of the risk of bias. Information sources comments by reviewers.

\begin{tabular}{|c|c|c|c|c|c|c|c|}
\hline & $\begin{array}{c}\text { Random Sequence } \\
\text { Generation (Selection Bias) }\end{array}$ & $\begin{array}{l}\text { Allocation } \\
\text { Concealment } \\
\text { (Selection Bias) }\end{array}$ & $\begin{array}{c}\text { Blinding of } \\
\text { Participants and } \\
\text { Personnel } \\
\text { (Performance Bias) } \\
\end{array}$ & $\begin{array}{l}\text { Blinding of Outcome } \\
\text { Assessment }\end{array}$ & $\begin{array}{l}\text { Incomplete Outcomes } \\
\text { Data (Attrition Bias) }\end{array}$ & $\begin{array}{c}\text { Selective } \\
\text { Reporting } \\
\text { (Reporting Bias) }\end{array}$ & Other Bias \\
\hline \multirow{2}{*}{$\begin{array}{c}\text { Hosono S; } 2008 \\
\text { Randomized } \\
\text { controlled trial } \\
\text { Jan 2001-Dec 2002 } \\
N=40(20: 20)\end{array}$} & High Risk & Low Risk & Low Risk & Unclear & Low Risk & Low Risk & Low Risk \\
\hline & No information & $\begin{array}{l}\text { Serially numbered } \\
\text { opaque envelopes }\end{array}$ & $\begin{array}{l}\text { Not blinded: } \\
\text { Clinicians }\end{array}$ & $\begin{array}{l}\text { The variables measured as } \\
\text { principal outcomes do not } \\
\text { depend on blinding }\end{array}$ & $\begin{array}{l}\text { No missing values Follow } \\
\text { up: Not stated (but at least } \\
84 \text { days according to the } \\
\text { Kaplan-Meier curves plot) }\end{array}$ & & \\
\hline \multirow[b]{2}{*}{$\begin{array}{c}\text { Rabe } \mathbf{H} ; \mathbf{2 0 1 1} \\
\text { Randomized } \\
\text { controlled trial } \\
\text { No date } \\
N=58(31: 27)\end{array}$} & High Risk & Low Risk & Low Risk & Unclear & Low Risk & Low Risk & Low Risk \\
\hline & $\begin{array}{l}\text { Randomization was based on } \\
\text { computer-created tables } \\
\text { performed by a person not } \\
\text { involved in the trial (stratified } \\
\text { by gestational age) }\end{array}$ & $\begin{array}{l}\text { Sealed opaque } \\
\text { envelopes and } \\
\text { consecutively } \\
\text { numbered. }\end{array}$ & $\begin{array}{l}\text { Not blinded: } \\
\text { Clinicians }\end{array}$ & $\begin{array}{l}\text { The variables measured as } \\
\text { principal outcomes do not } \\
\text { depend on blinding }\end{array}$ & $\begin{array}{l}\text { No missing values } \\
\text { Follow up: } 42 \text { days }\end{array}$ & & $\begin{array}{l}\text { According to sample size } \\
\text { calculation, they need } 58 \text { ( } 29 \\
\text { in each group and then } 27 \\
\text { and 31, possible poor } \\
\text { randomization or loss of } \\
\text { random sequence masking }\end{array}$ \\
\hline \multirow[b]{2}{*}{$\begin{array}{l}\text { March MI, } 2013 \\
\text { Randomized } \\
\text { controlled trial } \\
\text { Sep 2009-Jun 2011 } \\
N=75(36: 39)\end{array}$} & High Risk & Low Risk & Low Risk & Unclear & Low Risk & Low Risk & Low Risk \\
\hline & $\begin{array}{l}\text { Were randomized before } \\
\text { delivery to one of two groups } \\
\text { using random permuted blocks } \\
\text { of 10; an independent } \\
\text { statistician provided the } \\
\text { randomization sequence }\end{array}$ & $\begin{array}{l}\text { Serially numbered } \\
\text { opaque envelopes } \\
\text { contained arm } \\
\text { bands }\end{array}$ & $\begin{array}{l}\text { Neonatologists and } \\
\text { pediatric support staff } \\
\text { were not blinded to } \\
\text { treatment assignment }\end{array}$ & $\begin{array}{l}\text { They were not alerted for } \\
\text { study participation or } \\
\text { treatment assignment and } \\
\text { no notation of study } \\
\text { participation }\end{array}$ & $\begin{array}{l}\text { Control } 18 \text { missing values } \\
\text { Milking } 20 \text { missing values } \\
\text { Follow up: } 28 \text { days }\end{array}$ & & \\
\hline \multirow[b]{2}{*}{$\begin{array}{l}\text { Katheria A; } 2014 \\
\text { Randomized } \\
\text { controlled trial } \\
\text { Feb 2011-Jan 2013 } \\
N=60(30: 60)\end{array}$} & High Risk & Low Risk & Low Risk & Unclear & Low Risk & Low Risk & Low Risk \\
\hline & $\begin{array}{l}\text { Infants were randomized by the } \\
\text { placement of their information } \\
\text { in opaque, sealed envelopes. } \\
\text { The randomization cards } \\
\text { assigned a subject identification } \\
\text { number that was kept by the } \\
\text { research coordinator }\end{array}$ & $\begin{array}{c}\text { In opaque, sealed } \\
\text { envelopes }\end{array}$ & $\begin{array}{l}\text { Not blinded: } \\
\text { Clinicians }\end{array}$ & $\begin{array}{l}\text { Blinded serial } \\
\text { echocardiographic } \\
\text { examinations were } \\
\text { performed }\end{array}$ & No missing values & & \\
\hline \multirow[b]{2}{*}{$\begin{array}{c}\text { Alan S; 2014 } \\
\text { Randomized } \\
\text { controlled trial } \\
\text { Apr 2011-Feb 2013 } \\
N=44(22: 22)\end{array}$} & High Risk & Low Risk & Low Risk & Unclear & Low Risk & Low Risk & Low Risk \\
\hline & $\begin{array}{l}\text { Subjects were randomly } \\
\text { assigned to one of the two } \\
\text { experimental groups }\end{array}$ & $\begin{array}{c}\text { Sequentially } \\
\text { numbered sealed } \\
\text { non-transparent } \\
\text { envelopes }\end{array}$ & $\begin{array}{l}\text { The intervention was } \\
\text { unmasked for the } \\
\text { attending neonatal } \\
\text { and obstetric teams in } \\
\text { the delivery room }\end{array}$ & $\begin{array}{l}\text { Nothing stated. Some } \\
\text { principal variables do not } \\
\text { depend on blinding }\end{array}$ & $\begin{array}{l}\text { Five missing values in each } \\
\text { group } \\
\text { Follow up: } 28 \text { days }\end{array}$ & & \\
\hline \multirow{2}{*}{$\begin{array}{l}\text { Josephen; 2014 } \\
\text { Randomized } \\
\text { controlled trial } \\
\text { Up to Aug 2013 } \\
N=26(13: 13) \\
\end{array}$} & High Risk & Low Risk & Low Risk & Unclear & Low Risk & Low Risk & Low Risk \\
\hline & No information & No information & No information & $\begin{array}{l}\text { Nothing stated. Some } \\
\text { principal variables do not } \\
\text { depend on blinding }\end{array}$ & No information & No information & No information \\
\hline
\end{tabular}


Table A2. Cont.

\begin{tabular}{|c|c|c|c|c|c|c|c|}
\hline & $\begin{array}{c}\text { Random Sequence } \\
\text { Generation (Selection Bias) }\end{array}$ & $\begin{array}{l}\text { Allocation } \\
\text { Concealment } \\
\text { (Selection Bias) }\end{array}$ & $\begin{array}{c}\text { Blinding of } \\
\text { Participants and } \\
\text { Personnel } \\
\text { (Performance Bias) } \\
\end{array}$ & $\begin{array}{l}\text { Blinding of Outcome } \\
\text { Assessment }\end{array}$ & $\begin{array}{l}\text { Incomplete Outcomes } \\
\text { Data (Attrition Bias) }\end{array}$ & $\begin{array}{c}\text { Selective } \\
\text { Reporting } \\
\text { (Reporting Bias) }\end{array}$ & Other Bias \\
\hline \multirow[b]{2}{*}{$\begin{array}{l}\text { Katheria A; } 2015 \\
\text { Randomized } \\
\text { controlled trial } \\
N=154(75: 79)\end{array}$} & High Risk & Low Risk & Low Risk & Unclear & Low Risk & Low Risk & Low Risk \\
\hline & $\begin{array}{l}\text { Computer-generated } \\
\text { randomization }\end{array}$ & $\begin{array}{l}\text { Opaque, sealed } \\
\text { envelopes }\end{array}$ & $\begin{array}{l}\text { The blinding was } \\
\text { achieved by allowing } \\
\text { only the nurse } \\
\text { attending the delivery } \\
\text { and the obstetrician } \\
\text { performing the } \\
\text { intervention to be } \\
\text { aware of the allocation } \\
\text { arm }\end{array}$ & $\begin{array}{l}\text { Blinded echocardiograms } \\
\text { and head ultrasounds were } \\
\text { performed }\end{array}$ & $\begin{array}{l}\text { No missing values } \\
\text { Follow up: } 24 \mathrm{~h}\end{array}$ & & \\
\hline \multirow[b]{2}{*}{$\begin{array}{l}\text { Krueger MS; } 2015 \\
\text { Prospective } \\
\text { randomized trial } \\
\text { Aug 2012-Nov } \\
2013 \\
N=67(32: 35)\end{array}$} & High Risk & Low Risk & Low Risk & Unclear & Low Risk & Low Risk & Low Risk \\
\hline & $\begin{array}{l}\text { An equal number of envelopes } \\
\text { were created for each arm and } \\
\text { were scrambled by a third-party } \\
\text { registered nurse }\end{array}$ & Opaque envelopes & $\begin{array}{l}\text { The neonatal team } \\
\text { was not told which } \\
\text { patients were } \\
\text { participating in the } \\
\text { study, and the } \\
\text { randomization arm } \\
\text { was not documented } \\
\text { on the infants' charts }\end{array}$ & $\begin{array}{l}\text { Nothing stated. Some } \\
\text { principal variables do not } \\
\text { depend on blinding. Some } \\
\text { secondary outcomes may be } \\
\text { subjective. May have } \\
\text { blinded the assessor }\end{array}$ & No missing values & & \\
\hline \multirow[b]{2}{*}{$\begin{array}{l}\text { Kumar B; } 2015 \\
\text { Randomized } \\
\text { controlled trial } \\
2013-14 \\
N=200(100: 100)\end{array}$} & High Risk & Low Risk & Low Risk & Unclear & Low Risk & Low Risk & Low Risk \\
\hline & $\begin{array}{l}\text { Used an online generated } \\
\text { random number list }\end{array}$ & $\begin{array}{c}\text { Sealed envelope } \\
\text { was opened by a } \\
\text { delivery room staff } \\
\text { nurse } \\
\end{array}$ & Open-label & $\begin{array}{l}\text { Nothing stated. Some } \\
\text { variables may be subjective. } \\
\text { They may have blinded the } \\
\text { analyst }\end{array}$ & $\begin{array}{c}\text { Control: } 14 \text { missing values } \\
\text { Experimental: nine missing } \\
\text { values } \\
\text { Follow up: six weeks }\end{array}$ & & \\
\hline \multirow[b]{2}{*}{$\begin{array}{l}\text { Kilicdag H, } 2015 \\
\text { Prospective } \\
\text { randomized study } \\
\text { Aug 2012-Aug } \\
2013 \\
N=54(25: 29)\end{array}$} & High Risk & Low Risk & Low Risk & Unclear & Low Risk & Low Risk & Low Risk \\
\hline & $\begin{array}{l}\text { Were randomly assigned to one } \\
\text { of the two groups }\end{array}$ & $\begin{array}{l}\text { Using sequentially } \\
\text { numbered sealed } \\
\text { non-transparent } \\
\text { envelopes }\end{array}$ & No information & $\begin{array}{l}\text { Nothing stated. Some } \\
\text { variables may be subjective, } \\
\text { but it is not clear (segments, } \\
\text { bands).If not subjective then } \\
\text { low risk. Still, they may } \\
\text { have blinded the analyst }\end{array}$ & $\begin{array}{l}\text { Follow up: } \\
\text { seven days }\end{array}$ & & \\
\hline \multirow{2}{*}{$\begin{array}{c}\text { Das S; 2017 } \\
\text { Randomized } \\
\text { controlled trial } \\
\text { Nov 2012-Dec } \\
2013 \\
N=215(116: 99)\end{array}$} & High Risk & Low Risk & Low Risk & Unclear & Low Risk & Low Risk & Low Risk \\
\hline & $\begin{array}{l}\text { Random sequence was } \\
\text { generated using a secure } \\
\text { web-based randomization } \\
\text { algorithm }\end{array}$ & $\begin{array}{l}\text { Serially numbered, } \\
\text { sealed, and } \\
\text { opaque envelopes }\end{array}$ & $\begin{array}{l}\text { Blinding of the } \\
\text { personnel and } \\
\text { participants was not } \\
\text { feasible due to the } \\
\text { nature of intervention }\end{array}$ & $\begin{array}{l}\text { The laboratory person who } \\
\text { analyzed the serum ferritin } \\
\text { levels was blinded to group } \\
\text { allocation }\end{array}$ & Follow up: three months & & \\
\hline
\end{tabular}


Table A2. Cont.

\begin{tabular}{|c|c|c|c|c|c|c|c|}
\hline & $\begin{array}{c}\text { Random Sequence } \\
\text { Generation (Selection Bias) }\end{array}$ & $\begin{array}{l}\text { Allocation } \\
\text { Concealment } \\
\text { (Selection Bias) }\end{array}$ & $\begin{array}{c}\text { Blinding of } \\
\text { Participants and } \\
\text { Personnel } \\
\text { (Performance Bias) } \\
\end{array}$ & $\begin{array}{l}\text { Blinding of Outcome } \\
\text { Assessment }\end{array}$ & $\begin{array}{l}\text { Incomplete Outcomes } \\
\text { Data (Attrition Bias) }\end{array}$ & $\begin{array}{c}\text { Selective } \\
\text { Reporting } \\
\text { (Reporting Bias) }\end{array}$ & Other Bias \\
\hline \multirow{3}{*}{$\begin{array}{c}\text { Song S; 2017 } \\
\text { Randomized } \\
\text { controlled trial } \\
\text { Mar 2012-Jun 2015 } \\
N=66(34: 32) \\
\end{array}$} & High Risk & Low Risk & Low Risk & Unclear & Low Risk & Low Risk & Low Risk \\
\hline & $\begin{array}{c}\text { Randomized by } \\
\text { computer-generated random } \\
\text { numbers just before delivery }\end{array}$ & No information & No information & No information & No information & No information & No information \\
\hline & High Risk & Low Risk & Low Risk & Unclear & Low Risk & Low Risk & Low Risk \\
\hline $\begin{array}{c}\text { Katheria A; } 2017 \\
\text { Randomized } \\
\text { controlled trial } \\
\text { Aug 2013-Aug } \\
2014 \\
N=197 \text { (99:98) }\end{array}$ & $\begin{array}{l}\text { Using computer-generated } \\
\text { allocation }\end{array}$ & $\begin{array}{l}\text { Sealed envelopes } \\
\text { before delivery }\end{array}$ & $\begin{array}{l}\text { The blinding was } \\
\text { achieved by allowing } \\
\text { only the ALS nurse } \\
\text { attending the delivery } \\
\text { and the obstetrician } \\
\text { performing the } \\
\text { intervention to be } \\
\text { aware of the allocation } \\
\text { arm }\end{array}$ & $\begin{array}{l}\text { Neurodevelopmental } \\
\text { assessment was carried out } \\
\text { by examiners who were } \\
\text { trained in administration of } \\
\text { the Bayley-III, had excellent } \\
\text { inter-rater reliability }(0.90) \text {, } \\
\text { and masked to the umbilical } \\
\text { cord milking or DCC status }\end{array}$ & $\begin{array}{c}\text { Milking: } 23 \text { missing values } \\
\text { (a lot) DCC: } 25 \text { missing } \\
\text { values (a lot) } \\
\text { Follow up: two years }\end{array}$ & & \\
\hline \multirow[b]{2}{*}{$\begin{array}{c}\text { Lago; 2018 } \\
\text { Randomized } \\
\text { controlled trial } \\
\text { Feb 2013-Apr 2016 } \\
N=138(69: 69)\end{array}$} & High Risk & Low Risk & Low Risk & Unclear & Low Risk & Low Risk & Low Risk \\
\hline & $\begin{array}{l}\text { Patients were randomized into } \\
\text { one of the two groups: MM or } \\
\text { ECC. }\end{array}$ & $\begin{array}{c}\text { Randomization } \\
\text { was carried out by } \\
\text { a sealed } \\
\text { non-transparent } \\
\text { envelope and took } \\
\text { place just prior to } \\
\text { birth }\end{array}$ & $\begin{array}{l}\text { The neonatologist was } \\
\text { not aware of the } \\
\text { timing of cord } \\
\text { clamping. Special } \\
\text { attention was paid to } \\
\text { mask the intervention } \\
\text { to the neonatology } \\
\text { staff members (both } \\
\text { physician and nurses) } \\
\text { who were at the } \\
\text { delivery room or } \\
\text { theatre giving the first } \\
\text { clinical care to the } \\
\text { infants }\end{array}$ & $\begin{array}{l}\text { Addition, the cord clamping } \\
\text { interval was not registered } \\
\text { in the infant's chart, so this } \\
\text { information was not } \\
\text { available for the staff in the } \\
\text { neonatal intensive care unit } \\
\text { (NICU). }\end{array}$ & $\begin{array}{l}21 \text { missing values or } \\
\text { exclusions } \\
\text { Follow up: } \\
\text { six months }\end{array}$ & & \\
\hline \multirow[b]{2}{*}{$\begin{array}{l}\text { El-Naggar; } 2018 \\
\text { Randomized } \\
\text { controlled trial } \\
N=73(37: 36)\end{array}$} & High Risk & Low Risk & Low Risk & Unclear & Low Risk & Low Risk & Low Risk \\
\hline & $\begin{array}{l}\text { Was established using variable } \\
\text { block sizes randomization table }\end{array}$ & $\begin{array}{c}\text { Concealed opaque } \\
\text { envelopes were } \\
\text { prepared } \\
\text { ahead of time and } \\
\text { were opened just } \\
\text { before the time of } \\
\text { delivery }\end{array}$ & $\begin{array}{l}\text { Despite our efforts to } \\
\text { keep the healthcare } \\
\text { providers blinded to } \\
\text { the study intervention } \\
\text { by not documenting } \\
\text { the intervention in the } \\
\text { charts, we cannot be } \\
\text { absolutely sure that } \\
\text { full blinding was } \\
\text { achieved }\end{array}$ & $\begin{array}{l}\text { Both the echocardiographer } \\
\text { and the offline reader were } \\
\text { blinded to patient's } \\
\text { assignment }\end{array}$ & $\begin{array}{l}\text { No missing values } \\
\text { Follow up: } 48 \mathrm{~h}\end{array}$ & & \\
\hline
\end{tabular}


Table A2. Cont.

\begin{tabular}{|c|c|c|c|c|c|c|c|}
\hline & $\begin{array}{c}\text { Random Sequence } \\
\text { Generation (Selection Bias) }\end{array}$ & $\begin{array}{l}\text { Allocation } \\
\text { Concealment } \\
\text { (Selection Bias) }\end{array}$ & $\begin{array}{c}\text { Blinding of } \\
\text { Participants and } \\
\text { Personnel } \\
\text { (Performance Bias) } \\
\end{array}$ & $\begin{array}{l}\text { Blinding of Outcome } \\
\text { Assessment }\end{array}$ & $\begin{array}{l}\text { Incomplete Outcomes } \\
\text { Data (Attrition Bias) }\end{array}$ & $\begin{array}{c}\text { Selective } \\
\text { Reporting } \\
\text { (Reporting Bias) }\end{array}$ & Other Bias \\
\hline \multirow{2}{*}{$\begin{array}{c}\text { Shirk; 2019 } \\
\text { Randomized } \\
\text { controlled trial } \\
\text { Apr 2014-Jun 2018 } \\
N=204(104: 100) \\
\end{array}$} & High Risk & Low Risk & Low Risk & Unclear & Low Risk & Low Risk & Low Risk \\
\hline & $\begin{array}{l}\text { The patients were assigned } \\
\text { randomly via block } \\
\text { randomization with an } \\
\text { allocation ratio of } 1: 1\end{array}$ & $\begin{array}{l}\text { Sealed opaque } \\
\text { envelopes }\end{array}$ & Unblinded & $\begin{array}{l}\text { Nothing stated. Some } \\
\text { variables do not depend on } \\
\text { blinding. They may have } \\
\text { blinded the analyst }\end{array}$ & & & \\
\hline & High Risk & Low Risk & Low Risk & Unclear & Low Risk & Low Risk & Low Risk \\
\hline $\begin{array}{l}\text { Katheria; } 2019 \\
\text { Randomized } \\
\text { controlled trial } \\
\text { Jun 2017-Dec 2018 } \\
N=474(236: 238)\end{array}$ & $\begin{array}{c}\text { Opened a sequentially } \\
\text { numbered opaque } \\
\text { randomization envelope from } \\
\text { the appropriate gestational age } \\
\text { strata ( } 23 \text { weeks } 0 \text { days through } \\
27 \text { weeks six days or } 28 \text { weeks } \\
\text { zero days through } 31 \text { weeks six } \\
\text { days). Randomization was } \\
\text { computer generated using } \\
\text { permuted block sizes of two } \\
\text { and four and was stratified by } \\
\text { site }\end{array}$ & $\begin{array}{l}\text { Opaque envelopes } \\
\text { prior to delivery }\end{array}$ & $\begin{array}{l}\text { All outcome } \\
\text { assessments were } \\
\text { performed by blinded } \\
\text { team members }\end{array}$ & $\begin{array}{l}\text { Were adjudicated by two } \\
\text { independent pediatric } \\
\text { radiologists or } \\
\text { neuroradiologists who were } \\
\text { not affiliated with any of the } \\
\text { study sites and were } \\
\text { blinded to randomization } \\
\text { assignment }\end{array}$ & $\begin{array}{l}\text { No missing data were } \\
\text { identified for the primary } \\
\text { outcome of incidence of } \\
\text { death or severe } \\
\text { intraventricular } \\
\text { hemorrhage at } 6 \text { months' } \\
\text { corrected gestational age }\end{array}$ & & \\
\hline
\end{tabular}


Table A3. Categorical variables under study in preterm infants.

\begin{tabular}{|c|c|c|c|c|c|c|c|c|c|c|c|c|c|c|}
\hline \multirow[b]{2}{*}{ Author } & \multicolumn{2}{|c|}{ Mortality } & \multicolumn{2}{|c|}{ Hypot. Expanders } & \multicolumn{2}{|c|}{ Hypot. Drugs } & \multicolumn{2}{|c|}{$\begin{array}{c}\text { Respiratory Distress } \\
\text { Syndrome }\end{array}$} & \multicolumn{2}{|c|}{$\begin{array}{l}\text { Necrotizing } \\
\text { Enterocolitis }\end{array}$} & \multicolumn{2}{|c|}{ Sepsis } & \multicolumn{2}{|c|}{$\begin{array}{l}\text { Intraventricular } \\
\text { Hemorrhage }\end{array}$} \\
\hline & Milking & Control & Milking & Control & Milking & Control & Milking & Control & Milking & Control & Milking & Control & Milking & Control \\
\hline 2008; Hosono & $2 / 20$ & $3 / 20$ & NR & NR & NR & NR & $14 / 20$ & $13 / 20$ & NR & NR & $2 / 20$ & $1 / 20$ & $3 / 20$ & $5 / 20$ \\
\hline 2011; Rabe & $2 / 27$ & $4 / 31$ & NR & NR & NR & NR & NR & NR & $1 / 27$ & $4 / 31$ & $1 / 27$ & $0 / 31$ & $3 / 27$ & $7 / 31$ \\
\hline 2013; March & $2 / 36$ & $4 / 39$ & NR & NR & $0 / 36$ & $1 / 39$ & $36 / 36$ & $39 / 39$ & $6 / 36$ & $10 / 39$ & $10 / 36$ & $18 / 39$ & $9 / 36$ & $20 / 39$ \\
\hline 2014; Katheria & $2 / 30$ & $1 / 30$ & $11 / 30$ & $12 / 30$ & $10 / 30$ & $10 / 30$ & NR & NR & NR & NR & NR & NR & $8 / 30$ & $11 / 30$ \\
\hline 2014; Alan & NR & NR & NR & NR & NR & NR & NR & NR & $2 / 19$ & $1 / 19$ & $16 / 19$ & $16 / 19$ & $3 / 19$ & $0 / 19$ \\
\hline 2014; Josephen & NR & NR & NR & NR & NR & NR & NR & NR & NR & NR & NR & NR & NR & NR \\
\hline 2015; Katheria & $2 / 75$ & $6 / 79$ & NR & NR & NR & NR & NR & NR & $1 / 75$ & $0 / 79$ & $5 / 75$ & $3 / 79$ & $5 / 75$ & $10 / 79$ \\
\hline 2015; Krueger & $0 / 35$ & $3 / 32$ & NR & NR & NR & NR & NR & NR & NR & NR & NR & NR & $5 / 35$ & $4 / 32$ \\
\hline 2015; Kumar & NR & NR & NR & NR & NR & NR & $10 / 100$ & $5 / 100$ & NR & NR & NR & NR & NR & NR \\
\hline 2015; Kilicdag & NR & NR & NR & NR & NR & NR & NR & NR & NR & NR & NR & NR & NR & NR \\
\hline 2017; Das & NR & NR & NR & NR & NR & NR & NR & NR & $1 / 107$ & $1 / 90$ & $7 / 107$ & $8 / 90$ & $6 / 107$ & $3 / 90$ \\
\hline 2017; Song & $2 / 34$ & $9 / 32$ & NR & NR & $10 / 34$ & $20 / 32$ & NR & NR & $0 / 34$ & $1 / 32$ & $23 / 34$ & $25 / 32$ & NR & NR \\
\hline 2017; Katheria & NR & NR & NR & NR & $8 / 70$ & $12 / 65$ & NR & NR & NR & NR & $4 / 70$ & $1 / 65$ & $9 / 70$ & $6 / 65$ \\
\hline 2018; Lago & $0 / 69$ & $0 / 69$ & NR & NR & $3 / 69$ & $1 / 69$ & $16 / 69$ & $8 / 69$ & $2 / 69$ & $1 / 69$ & NR & NR & $4 / 69$ & $4 / 69$ \\
\hline 2018; El-Naggar & $1 / 37$ & $1 / 36$ & $1 / 37$ & $0 / 36$ & $1 / 37$ & $0 / 36$ & NR & NR & $4 / 37$ & $4 / 36$ & NR & NR & $13 / 37$ & $10 / 36$ \\
\hline 2019; Shirk & $5 / 100$ & $4 / 104$ & NR & NR & NR & NR & NR & NR & $3 / 100$ & $6 / 104$ & NR & NR & $10 / 100$ & $16 / 104$ \\
\hline 2019;Katheria & $17 / 236$ & $15 / 238$ & NR & NR & NR & NR & NR & NR & $8 / 236$ & $13 / 238$ & $25 / 236$ & $24 / 238$ & $57 / 236$ & $50 / 238$ \\
\hline Egger Bias ( $p$-value) & \multicolumn{2}{|c|}{0.165} & \multicolumn{2}{|c|}{$\mathrm{NC}$} & \multicolumn{2}{|c|}{0.299} & \multicolumn{2}{|c|}{$\mathrm{NC}$} & \multicolumn{2}{|c|}{0.315} & \multicolumn{2}{|c|}{0.205} & \multicolumn{2}{|c|}{0.787} \\
\hline $\mathrm{I}^{2} 95 \% \mathrm{CI}$ & \multicolumn{2}{|c|}{$0 \%(0-52.7)$} & \multicolumn{2}{|c|}{ NC } & \multicolumn{2}{|c|}{$7.3 \%(0-63.8)$} & \multicolumn{2}{|c|}{$39.6 \%(0-82.3)$} & \multicolumn{2}{|c|}{$0 \%(0-52.7)$} & \multicolumn{2}{|c|}{$0 \%(0-54.4)$} & \multicolumn{2}{|c|}{$11.1 \%(0-54.1)$} \\
\hline Cochran's Q ( $p$-value) & \multicolumn{2}{|c|}{0.482} & \multicolumn{2}{|c|}{0.475} & \multicolumn{2}{|c|}{0.370} & \multicolumn{2}{|c|}{0.191} & \multicolumn{2}{|c|}{0.920} & \multicolumn{2}{|c|}{0.615} & \multicolumn{2}{|c|}{0.334} \\
\hline RR 95\% CI & \multicolumn{2}{|c|}{$0.71(0.47-1.08)$} & $1(0.5$ & $-1.88)$ & $0.70(0$. & $8-1.03)$ & 1.54( & $3-2.29)$ & $0.71(0$. & $5-1.12)$ & $0.96(0$. & 7-1.19) & $0.93(0$ & $6-1.15)$ \\
\hline
\end{tabular}


Table A3. Cont.

\begin{tabular}{|c|c|c|c|c|c|c|c|c|c|c|c|c|}
\hline \multirow[b]{2}{*}{ Author } & \multicolumn{2}{|c|}{ Transfusion } & \multicolumn{2}{|c|}{ Phototherapy } & \multicolumn{2}{|c|}{ Oxygen at Birth } & \multicolumn{2}{|c|}{ Oxygen at 28 Days } & \multicolumn{2}{|c|}{$\begin{array}{l}\text { Patent Ductus } \\
\text { Arteriosus }\end{array}$} & \multicolumn{2}{|c|}{$\begin{array}{l}\text { Retinopathy of } \\
\text { Prematurity }\end{array}$} \\
\hline & Milking & Control & Milking & Control & Milking & Control & Milking & Control & Milking & Control & Milking & Control \\
\hline 2008; Hosono & $7 / 20$ & $14 / 20$ & NR & NR & NR & NR & NR & NR & $5 / 20$ & $7 / 20$ & $8 / 20$ & $17 / 20$ \\
\hline 2011; Rabe & $17 / 27$ & $15 / 31$ & NR & NR & NR & NR & $4 / 27$ & $6 / 31$ & NR & NR & $1 / 27$ & $0 / 31$ \\
\hline 2013; March & $30 / 36$ & $38 / 39$ & $33 / 36$ & $38 / 39$ & NR & NR & NR & NR & NR & NR & $28 / 36$ & $31 / 39$ \\
\hline 2014; Katheria & $11 / 30$ & $22 / 30$ & NR & NR & NR & NR & NR & NR & NR & NR & NR & NR \\
\hline 2014; Alan & $15 / 19$ & $17 / 19$ & NR & NR & NR & NR & NR & NR & NR & NR & NR & NR \\
\hline 2014; Josephen & NR & NR & NR & NR & NR & NR & NR & NR & NR & NR & NR & NR \\
\hline 2015; Katheria & $31 / 75$ & $41 / 79$ & NR & NR & $57 / 75$ & $56 / 79$ & $16 / 75$ & $12 / 79$ & NR & NR & $1 / 75$ & $2 / 79$ \\
\hline 2015; Krueger & NR & NR & NR & NR & NR & NR & NR & NR & NR & NR & $6 / 35$ & $4 / 32$ \\
\hline 2015; Kumar & NR & NR & NR & NR & NR & NR & NR & NR & NR & NR & NR & NR \\
\hline 2015; Kilicdag & NR & NR & NR & NR & NR & NR & NR & NR & NR & NR & NR & NR \\
\hline 2017; Das & NR & NR & $104 / 107$ & $89 / 90$ & NR & NR & NR & NR & NR & NR & $8 / 107$ & $3 / 90$ \\
\hline 2017; Song & NR & NR & NR & NR & $28 / 34$ & $31 / 32$ & NR & NR & NR & NR & $0 / 34$ & $2 / 32$ \\
\hline 2017; Katheria & NR & NR & NR & NR & NR & NR & NR & NR & NR & NR & NR & NR \\
\hline 2018; Lago & $4 / 69$ & $5 / 69$ & $41 / 69$ & $25 / 69$ & NR & NR & NR & NR & $14 / 69$ & $7 / 69$ & NR & NR \\
\hline 2018; El-Naggar & NR & NR & $36 / 37$ & $33 / 36$ & $31 / 37$ & $26 / 36$ & NR & NR & $12 / 37$ & $10 / 36$ & $2 / 37$ & $3 / 36$ \\
\hline 2019; Shirk & $9 / 100$ & $16 / 104$ & $85 / 100$ & $88 / 104$ & NR & NR & NR & NR & NR & NR & NR & NR \\
\hline 2019; Katheria & NR & NR & NR & NR & NR & NR & NR & NR & $42 / 236$ & $46 / 238$ & $10 / 236$ & $19 / 238$ \\
\hline Egger Bias ( $p$-value) & \multicolumn{2}{|c|}{0.345} & \multicolumn{2}{|c|}{0.208} & \multicolumn{2}{|c|}{ NC } & \multicolumn{2}{|c|}{$\mathrm{NC}$} & \multicolumn{2}{|c|}{0.595} & \multicolumn{2}{|c|}{0.688} \\
\hline $\mathrm{I}^{2} 95 \% \mathrm{CI}$ & \multicolumn{2}{|c|}{$42.1 \%(0-72.9)$} & \multicolumn{2}{|c|}{$81.9 \%(46.5-90.5)$} & \multicolumn{2}{|c|}{$67.2 \%(0-88.4)$} & \multicolumn{2}{|c|}{$\mathrm{NC}$} & \multicolumn{2}{|c|}{$11.7 \%(0-71.5)$} & \multicolumn{2}{|c|}{$35.2 \%(0-69.1)$} \\
\hline Cochran's Q ( $p$-value) & \multicolumn{2}{|c|}{0.098} & \multicolumn{2}{|c|}{$<0.001$} & \multicolumn{2}{|c|}{0.047} & \multicolumn{2}{|c|}{0.375} & \multicolumn{2}{|c|}{0.334} & \multicolumn{2}{|c|}{0.136} \\
\hline RR 95\% CI & \multicolumn{2}{|c|}{$0.78(0.67-0.90)$} & \multicolumn{2}{|c|}{$1.03(0.92-1.15)^{*}$} & \multicolumn{2}{|c|}{$1.01(0.82-1.23)^{*}$} & \multicolumn{2}{|c|}{$1.20(0.67-2.14)$} & \multicolumn{2}{|c|}{$1.04(0.78-1.40)$} & \multicolumn{2}{|c|}{$0.80(0.63-1.03)$} \\
\hline
\end{tabular}

RR: Relative Risk. NR: Non reported; NC: Not calculated; CI: Confidence Interval. * Random effects (DerSimonian-Laird). Bold means statistically significant differences. 
Table A4. Quantitative variables under study in preterm infants.

\begin{tabular}{|c|c|c|c|c|c|c|c|c|c|c|c|c|c|c|c|c|}
\hline \multirow[b]{2}{*}{ Author } & \multicolumn{2}{|c|}{ Hemoglobin } & \multicolumn{2}{|c|}{ Hematocrit } & \multicolumn{2}{|c|}{$\begin{array}{l}\text { Mean Blood } \\
\text { Pressure }\end{array}$} & \multicolumn{2}{|c|}{$\begin{array}{c}\text { Length of Hospital } \\
\text { Stay }\end{array}$} & \multicolumn{2}{|c|}{ Cord Arterial pH } & \multicolumn{2}{|c|}{$\begin{array}{c}\text { Peak Serum } \\
\text { Bilirubin, Median }\end{array}$} & \multicolumn{2}{|c|}{ Apgar Scores $1 \mathrm{~min}$} & \multicolumn{2}{|c|}{ Apgar Scores $5 \mathrm{~min}$} \\
\hline & Milking & Control & Milking & Control & Milking & Control & Milking & Control & Milking & Control & Milking & Control & Milking & Control & Milking & Control \\
\hline 2008; Hosono & $16.5(1.4)$ & $14.1(1.6)$ & NR & NR & $34.0(9.0)$ & $28.0(8.0)$ & NR & NR & NR & NR & $\begin{array}{c}8.18 \\
(2.57)\end{array}$ & $\begin{array}{l}7.83 \\
(2.45)\end{array}$ & $5.40(2.0)$ & $\begin{array}{c}4.20 \\
(1.80)\end{array}$ & $7.3(1.7)$ & $6.9(1.7)$ \\
\hline 2011; Rabe & NR & NR & $52.0(8.0)$ & $51.0(7.0)$ & $35.0(8.0)$ & $31.0(6.0)$ & $\begin{array}{c}105 \\
(75.62)\end{array}$ & $\begin{array}{c}72.5 \\
(45.76)\end{array}$ & $7.2(0.15)$ & $7.2(0.09)$ & $\begin{array}{l}10.17 \\
(3.09)\end{array}$ & $\begin{array}{l}10.34 \\
(1.81)\end{array}$ & NR & NR & $7.0(2.00)$ & $8.5(0.97)$ \\
\hline 2013; March & $\begin{array}{l}15.43 \\
(3.70)\end{array}$ & $\begin{array}{l}13.73 \\
(1.84) \\
\end{array}$ & $\begin{array}{c}45.6 \\
(10.57)\end{array}$ & $\begin{array}{l}40.63 \\
(5.31) \\
\end{array}$ & NR & NR & NR & NR & $7.3(0.0)$ & $\begin{array}{l}7.33 \\
(0.07)\end{array}$ & $\begin{array}{l}5.16 \\
(0.84)\end{array}$ & $5.6(1.46)$ & $3.5(3.47)$ & $\begin{array}{l}3.66 \\
(2.30)\end{array}$ & $\begin{array}{l}6.16 \\
(1.54)\end{array}$ & $\begin{array}{c}6.33 \\
(1.53) \\
\end{array}$ \\
\hline 2014; Katheria & NR & NR & $43.0(7.0)$ & $46.0(7.0)$ & $41.0(9.0)$ & $36.0(9.0)$ & NR & NR & NR & NR & $8.0(2.0)$ & $7.0(2.0)$ & NR & NR & NR & NR \\
\hline 2014; Alan & $\begin{array}{l}16.62 \\
(1.23)\end{array}$ & $\begin{array}{l}15.4 \\
(1.62)\end{array}$ & NR & NR & NR & NR & $\begin{array}{l}45.75 \\
(14.4)\end{array}$ & $\begin{array}{c}51.5 \\
(17.28)\end{array}$ & NR & NR & NR & NR & $\begin{array}{c}6.25 \\
(1.30)\end{array}$ & $6.0(1.57)$ & $\begin{array}{l}7.75 \\
(0.78)\end{array}$ & $7.5(1.04)$ \\
\hline 2014; Josephen & $13.9(2.8)$ & $13.4(1.8)$ & NR & NR & NR & NR & NR & NR & NR & NR & NR & NR & NR & NR & NR & NR \\
\hline 2015; Katheria & $16.3(2.4)$ & $15.6(2.2)$ & NR & NR & NR & NR & NR & NR & NR & NR & $8.1(2.9)$ & $7.3(2.2)$ & NR & NR & NR & NR \\
\hline 2015; Krueger & NR & NR & $\begin{array}{l}47.71 \\
(4.7)\end{array}$ & $\begin{array}{l}47.75 \\
(8.3)\end{array}$ & NR & NR & $\begin{array}{l}67.8 \\
(29.0) \\
\end{array}$ & $\begin{array}{c}71.2 \\
(33.0) \\
\end{array}$ & NR & NR & $8.27(2.6)$ & $8.38(2.6)$ & NR & NR & NR & NR \\
\hline 2015; Kumar & $16.7(2.3)$ & $16(2.7)$ & NR & NR & $50(11.4)$ & $48(10.2)$ & NR & NR & NR & NR & NR & NR & $\begin{array}{l}6.90 \\
(0.30) \\
\end{array}$ & $\begin{array}{c}6.90 \\
(0.30) \\
\end{array}$ & NR & NR \\
\hline 2015; Kilicdag & $18.2(2.3)$ & $17.6(2.1)$ & $52.3(6.1)$ & $51.3(6.3)$ & NR & NR & NR & NR & NR & NR & NR & NR & $\begin{array}{l}5.75 \\
(1.23) \\
\end{array}$ & $\begin{array}{c}5.25 \\
(1.27) \\
\end{array}$ & $8.0(0.49)$ & $7.5(1.01)$ \\
\hline 2017; Das & $15.0(2.0)$ & $14.5(3.0)$ & $47.0(7.0)$ & $45.0(8.0)$ & NR & NR & NR & NR & NR & NR & NR & NR & NR & NR & $9.0(0.00)$ & $\begin{array}{c}8.66 \\
(0.75)\end{array}$ \\
\hline 2017; Song & $15.8(1.6)$ & $14.7(2.1)$ & NR & NR & $31.7(6.2)$ & $29.6(6.7)$ & $\begin{array}{c}54.7 \\
(19.3)\end{array}$ & $\begin{array}{l}51.5 \\
(44.8)\end{array}$ & $7.3(0.9)$ & $7.3(0.2)$ & NR & NR & $5.5(2.7)$ & $5.1(2.4)$ & $7.8(1.8)$ & $7.5(1.7)$ \\
\hline 2017; Katheria & $\begin{array}{l}16.35 \\
(2.39) \\
\end{array}$ & $\begin{array}{l}15.78 \\
(1.94)\end{array}$ & NR & NR & NR & NR & NR & NR & NR & NR & NR & NR & NR & NR & NR & NR \\
\hline 2018; Lago & $\begin{array}{l}17.93 \\
(2.96)\end{array}$ & $\begin{array}{l}16.23 \\
(2.80) \\
\end{array}$ & $\begin{array}{l}54.20 \\
(9.27) \\
\end{array}$ & $\begin{array}{l}48.83 \\
(8.76) \\
\end{array}$ & NR & NR & NR & NR & NR & NR & $\begin{array}{l}11.09 \\
(3.21)\end{array}$ & $\begin{array}{l}11.24 \\
(3.56)\end{array}$ & NR & NR & NR & NR \\
\hline 2018; El-Naggar & $16.1(2.3)$ & $15.0(2.4)$ & NR & NR & $33.0(5.6)$ & $34.0(5.2)$ & $\begin{array}{c}75.66 \\
(37.79)\end{array}$ & $\begin{array}{l}77.66 \\
(38.6) \\
\end{array}$ & NR & NR & $\begin{array}{l}9.76 \\
(2.47)\end{array}$ & $\begin{array}{c}9.01 \\
(1.89)\end{array}$ & $\begin{array}{c}4.66 \\
(0.77) \\
\end{array}$ & $\begin{array}{l}4.66 \\
(3.86)\end{array}$ & $\begin{array}{l}7.00 \\
(1.54)\end{array}$ & $\begin{array}{l}7.00 \\
(1.54) \\
\end{array}$ \\
\hline 2019; Shirk & $17.2(2.1)$ & $16.8(2.5)$ & $51.8(6.2)$ & $49.9(7.7)$ & NR & NR & NR & NR & $\begin{array}{c}7.14 \\
(0.77)\end{array}$ & $\begin{array}{c}7.23 \\
(0.09) \\
\end{array}$ & $8.8(2.2)$ & $8.8(2.5)$ & $\begin{array}{c}6.66 \\
(2.25) \\
\end{array}$ & $\begin{array}{l}6.66 \\
(2.25) \\
\end{array}$ & $\begin{array}{l}8.00 \\
(1.50)\end{array}$ & $\begin{array}{c}8.33 \\
(1.50) \\
\end{array}$ \\
\hline 2019; Katheria & $16.5(3.1)$ & $16.4(2.7)$ & $48.6(8.2)$ & $48.6(7.9)$ & NR & NR & NR & NR & NR & NR & NR & NR & NR & NR & NR & NR \\
\hline Egger Bias ( $p$ value) & \multicolumn{2}{|c|}{0.037} & \multicolumn{2}{|c|}{0.526} & \multicolumn{2}{|c|}{0.007} & \multicolumn{2}{|c|}{0.039} & \multicolumn{2}{|c|}{0.969} & \multicolumn{2}{|c|}{0.313} & \multicolumn{2}{|c|}{0.1} & \multicolumn{2}{|c|}{0.177} \\
\hline $\mathrm{I}^{2} 95 \% \mathrm{CI}$ & \multicolumn{2}{|c|}{$53 \%(0-73)$} & \multicolumn{2}{|c|}{$61.2 \%(0-79.5)$} & \multicolumn{2}{|c|}{$52.9 \%(0-79.3)$} & \multicolumn{2}{|c|}{$24.1 \%(0-72.1)$} & \multicolumn{2}{|c|}{$0 \%(0-67.9)$} & \multicolumn{2}{|c|}{$35 \%(0-69)$} & \multicolumn{2}{|c|}{$0(0-56.3)$} & \multicolumn{2}{|c|}{$72.1(33.9-84.2)$} \\
\hline $\begin{array}{c}\text { Cochran's } Q \\
(p \text {-value })\end{array}$ & \multicolumn{2}{|c|}{0.01} & \multicolumn{2}{|c|}{0.008} & \multicolumn{2}{|c|}{0.059} & \multicolumn{2}{|c|}{0.260} & 0. & & 0.1 & 138 & 0.4 & & & 001 \\
\hline PWMD CI 95\% & $0.89(0.55$ & to 1.22$)^{b}$ & $1.43(-0.0$ & 3 to 2.89$)^{\mathrm{a}}$ & $1.92(0.5$ & 5 to 3.25$)$ & $-1.92(-8.4$ & to 4.60$)^{a}$ & $-0.03(-0$. & 5 to -0.01$)$ & $0.11(-0.1$ & 8 to 0.40$)^{a}$ & $0.02(-0.0$ & 6 to 0.1$)^{a}$ & $0.02(-0.3$ & to 0.35$)^{\mathrm{b}}$ \\
\hline
\end{tabular}

PWMD: Pooled weighted mean difference; NR: Non reported; ${ }^{a}$ Mantel-Haenszel fixed effect. ${ }^{b}$ Random effects Model (DerSimonian-Laird). Bold means statistically significant differences. 


\section{References}

1. Katheria, A.C.; Lakshminrusimha, S.; Rabe, H.; McAdams, R.; Mercer, J.S. Placental transfusion: A review. J. Perinatol. 2017, 37, 105-111. [CrossRef] [PubMed]

2. Brune, T.; Garritsen, H.; Witteler, R.; Schlake, A.; Wüllenweber, J.; Louwen, F.; Jorch, G.; Harms, E. Autologous placental blood transfusion for the therapy of anaemic neonates. Neonatology 2002, 81, 236-243. [CrossRef]

3. Farrar, D.; Airey, R.; Law, G.R.; Tuffnell, D.; Cattle, B.; Duley, L. Measuring placental transfusion for term births: Weighing babies with cord intact. BJOG 2011, 118, 70-75. [CrossRef]

4. Aladangady, N.; McHugh, S.; Aitchison, T.C.; Wardrop, C.A.J.; Holland, B.M. Infants' blood volume in a controlled trial of placental transfusion at preterm delivery. Pediatrics 2006, 117, 93-98. [CrossRef] [PubMed]

5. Hutton, E.K.; Hassan, E.S. Late vs. early clamping of the umbilical cord in full-term neonates: Systematic review and meta-analysis of controlled trials. JAMA 2007, 297, 1241-1252. [CrossRef] [PubMed]

6. Rabe, H.; Reynolds, G.J.; Diaz-Rosello, J.L. Early versus delayed umbilical cord clamping in preterm infants. In Cochrane Database of Systematic Reviews; Rabe, H., Ed.; John Wiley \& Sons, Ltd.: Chichester, UK, 2004; No. CD003248.

7. Fogarty, M.; Osborn, D.A.; Askie, L.; Seidler, A.L.; Hunter, K.; Lui, K.; Simes, J.; Tarnow-Mordi, W. Delayed vs. early umbilical cord clamping for preterm infants: A systematic review and meta-analysis. Am. J. Obstet. Gynecol. 2018, 218, 1-18. [CrossRef]

8. Grupo de trabajo de la Guía de Práctica Clínica sobre Atención al Parto Normal. Guía de Práctica Clínica sobre la Atención al Parto Normal. In Plan de Calidad para el Sistema Nacional de Salud del Ministerio de Sanidad y Politica Social; Agencia de Evaluació: Madrid, Spain, 2010.

9. National Institute for Health and Care Excellence. Intrapartum Care for Healthy Women and Babies; National Institute for Health and Care Excellence: London, UK, 2014.

10. WHO Recommendations on Intrapartum Care for a Positive Childbirth Experience; World Health Organization: Geneva, Switzerland, 2018.

11. American College of Nurse Midwives. Delayed Umbilical Cord Clamping. Position Stawtement; ACNM: Silver Spring, MD, USA, 2014.

12. Committee on Obstetric Practice. Committee opinion No. 684: Delayed umbilical cord clamping after birth. Obstet. Gynecol. 2017, 129, e5-e10. [CrossRef]

13. Al-Wassia, H.; Shah, P.S. Efficacy and safety of umbilical cord milking at birth: A systematic review and meta-analysis. JAMA Pediatr. 2015, 169, 18-25. [CrossRef]

14. Katheria, A.C. Umbilical Cord Milking: A Review. Front. Pediatr. 2018, 6, 335. [CrossRef]

15. Nagano, N.; Saito, M.; Sugiura, T.; Miyahara, F.; Namba, F.; Ota, E. Benefits of umbilical cord milking versus delayed cord clamping on neonatal outcomes in preterm infants: A systematic review and meta-analysis. PLOS ONE 2018, 13, e0201528. [CrossRef]

16. Josephsen, J.; Vlastos, E.; Potter, S.; Al-Hosni, M. Milking the umbilical cord in extreme preterm infants. Am. J. Obstet. Gynecol. 2014. [CrossRef]

17. Krueger, M.S.; Eyal, F.G.; Peevy, K.J.; Hamm, C.R.; Whitehurst, R.M.; Lewis, D.F. Delayed cord clamping with and without cord stripping: A prospective randomized trial of preterm neonates. Am. J. Obstet. Gynecol. 2015, 212, 394.e1-394.e5. [CrossRef]

18. Kumar, B.; Upadhyay, A.; Gothwal, S.; Jaiswal, V.; Joshi, P.; Dubey, K. Umbilical cord milking and hematological parameters in moderate to late preterm neonates: A randomized controlled trial. Indian Pediatr. 2015, 52, 753-757. [CrossRef] [PubMed]

19. Kilicdag, H.; Gulcan, H.; Hanta, D.; Torer, B.; Gokmen, Z.; Ozdemir, S.I.; Antmen, B.A. Is umbilical cord milking always an advantage? J. Matern. Neonatal Med. 2016, 29, 615-618. [CrossRef] [PubMed]

20. Das, B.; Sundaram, V.; Kumar, P.; Mordi, W.T.; Dhaliwal, L.K.; Das, R. Effect of placental transfusion on iron stores in moderately preterm neonates of 30-33 weeks gestation. Indian J. Pediatr. 2018, 85, 172-178. [CrossRef] [PubMed]

21. Song, S.-Y.; Kim, Y.; Kang, B.-H.; Yoo, H.-J.; Lee, M. Safety of umbilical cord milking in very preterm neonates: A randomized controlled study. Obstet. Gynecol. Sci. 2017, 60, 527. [CrossRef] 
22. Katheria, A.; Garey, D.; Truong, G.; Akshoomoff, N.; Steen, J.; Maldonado, M.; Poeltler, D.; Harbert, M.J.; Vaucher, Y.E.; Finer, N. A randomized clinical trial of umbilical cord milking vs. delayed cord clamping in preterm infants: Neurodevelopmental outcomes at 22-26 months of corrected age. J. Pediatr. 2018, 194, 76-80. [CrossRef]

23. Lago Leal, V.; Pamplona Bueno, L.; Cabanillas Vilaplana, L.; Nicolás Montero, E.; Martín Blanco, M.; Fernández Romero, C.; El Bakkali, S.; Pradillo Aramendi, T.; Sobrino Lorenzano, L.; Castellano Esparza, P.; et al. Effect of milking maneuver in preterm infants: A randomized controlled trial. Fetal Diagn. Ther. 2019, 45, 57-61. [CrossRef]

24. El-Naggar, W.; Simpson, D.; Hussain, A.; Armson, A.; Dodds, L.; Warren, A.; Whyte, R.; McMillan, D. Cord milking versus immediate clamping in preterm infants: Arandomised controlled trial. Arch. Dis. Child.Fetal Neonatal Ed. 2019, 104, F145-F150. [CrossRef]

25. Shirk, S.K.; Manolis, S.A.; Lambers, D.S.; Smith, K.L. Delayed clamping vs. milking of umbilical cord in preterm infants: A randomized controlled trial. Am. J. Obstet. Gynecol. 2019, 220, e1-e482. [CrossRef]

26. Katheria, A.; Reister, F.; Essers, J.; Mendler, M.; Hummler, H.; Subramaniam, A.; Carlo, W.; Tita, A.; Truong, G.; Davis-Nelson, S.; et al. Association of umbilical cord milking vs. delayed umbilical cord clamping with death or severe intraventricular hemorrhage among preterm infants. JAMA 2019, 322, 1877. [CrossRef]

27. Liberati, A.; Altman, D.G.; Tetzlaff, J.; Mulrow, C.; Gøtzsche, P.C.; Ioannidis, J.P.A.; Clarke, M.; Devereaux, P.J.; Kleijnen, J.; Moher, D. The PRISMA statement for reporting systematic reviews and meta-analyses of studies that evaluate health care interventions: Explanation and elaboration. Ann. Intern. Med. 2009, 151, W65-W94. [CrossRef] [PubMed]

28. Higgins, J.P.T.; Green, S. (Eds.) Chapter 7: Selecting studies and collecting data. In Cochrane Handbook for Systematic Reviews of Interventions Version 5.1.0; (Updated March 2011); The Cochrane Collaboration: London, UK, 2011.

29. Higgins, J.P.T.; Altman, D.G.; Gotzsche, P.C.; Juni, P.; Moher, D.; Oxman, A.D.; Savovic, J.; Schulz, K.F.; Weeks, L.; Sterne, J.A.C.; et al. The Cochrane Collaboration's tool for assessing risk of bias in randomised trials. BMJ 2011, 343, d5928. [CrossRef] [PubMed]

30. Higgins, J.P.T.; Thompson, S.G.; Deeks, J.J.; Altman, D.G. Measuring inconsistency in meta-analyses. BMJ 2003, 327, 557-560. [CrossRef] [PubMed]

31. Higgins, J.P.T.; Thompson, S.G. Quantifying heterogeneity in a meta-analysis. Stat. Med. 2002, 21, 1539-1558. [CrossRef] [PubMed]

32. Hosono, S.; Mugishima, H.; Fujita, H.; Hosono, A.; Minato, M.; Okada, T.; Takahashi, S.; Harada, K. Umbilical cord milking reduces the need for red cell transfusions and improves neonatal adaptation in infants born at less than 29 weeks' gestation: Arandomised controlled trial. Arch. Dis. Child. Fetal Neonatal Ed. 2008, 93, F14-F19. [CrossRef]

33. Rabe, H.; Jewison, A.; Fernandez Alvarez, R.; Crook, D.; Stilton, D.; Bradley, R.; Holden, D. Brighton perinatal study group milking compared with delayed cord clamping to increase placental transfusion in preterm neonates. Obstet. Gynecol. 2011, 117, 205-211. [CrossRef]

34. March, M.I.; Hacker, M.R.; Parson, A.W.; Modest, A.M.; de Veciana, M. The effects of umbilical cord milking in extremely preterm infants: A randomized controlled trial. J. Perinatol. 2013, 33, 763-767. [CrossRef]

35. Katheria, A.C.; Leone, T.A.; Woelkers, D.; Garey, D.M.; Rich, W.; Finer, N.N. The effects of umbilical cord milking on hemodynamics and neonatal outcomes in premature neonates. J. Pediatr. 2014, 164, 1045-1050. [CrossRef]

36. Katheria, A.C.; Truong, G.; Cousins, L.; Oshiro, B.; Finer, N.N. Umbilical cord milking versus delayed cord clamping in preterm infants. Pediatrics 2015, 136, 61-69. [CrossRef]

37. Alan, S.; Arsan, S.; Okulu, E.; Akin, I.M.; Kilic, A.; Taskin, S.; Cetinkaya, E.; Erdeve, O.; Atasay, B. Effects of umbilical cord milking on the need for packed red blood cell transfusions and early neonatal hemodynamic adaptation in preterm infants born $\leq 1500 \mathrm{~g}$ : A prospective, randomized, controlled trial. J. Pediatr. Hematol. Oncol. 2014, 36, e493-e498. [CrossRef]

38. Linderkamp, O. Placental transfusion: Determinants and effects. Clin. Perinatol. 1982, 9, 559-592. [CrossRef]

39. Bell, E.F.; Strauss, R.G.; Widness, J.A.; Mahoney, L.T.; Mock, D.M.; Seward, V.J.; Cress, G.A.; Johnson, K.J.; Kromer, I.J.; Zimmerman, M.B. Randomized trial of liberal versus restrictive guidelines for red blood cell transfusion in preterm infants. Pediatrics 2005, 115, 1685-1691. [CrossRef] [PubMed] 
40. Dang, D.; Zhang, C.; Shi, S.; Mu, X.; Lv, X.; Wu, H. Umbilical cord milking reduces need for red cell transfusions and improves neonatal adaptation in preterm infants: Meta-analysis. J. Obstet. Gynaecol. Res. 2015, 41, 890-895. [CrossRef] [PubMed]

41. Blank, D.A.; Polglase, G.R.; Kluckow, M.; Gill, A.W.; Crossley, K.J.; Moxham, A.; Rodgers, K.; Zahra, V.; Inocencio, I.; Stenning, F.; et al. Haemodynamic effects of umbilical cord milking in premature sheep during the neonatal transition. Arch. Dis. Child. Fetal Neonatal Ed. 2018, 103, F539-F546. [CrossRef] [PubMed]

(C) 2020 by the authors. Licensee MDPI, Basel, Switzerland. This article is an open access article distributed under the terms and conditions of the Creative Commons Attribution (CC BY) license (http://creativecommons.org/licenses/by/4.0/). 